Historic, Archive Document

Do not assume content reflects current scientific knowledge, policies, or practices. 


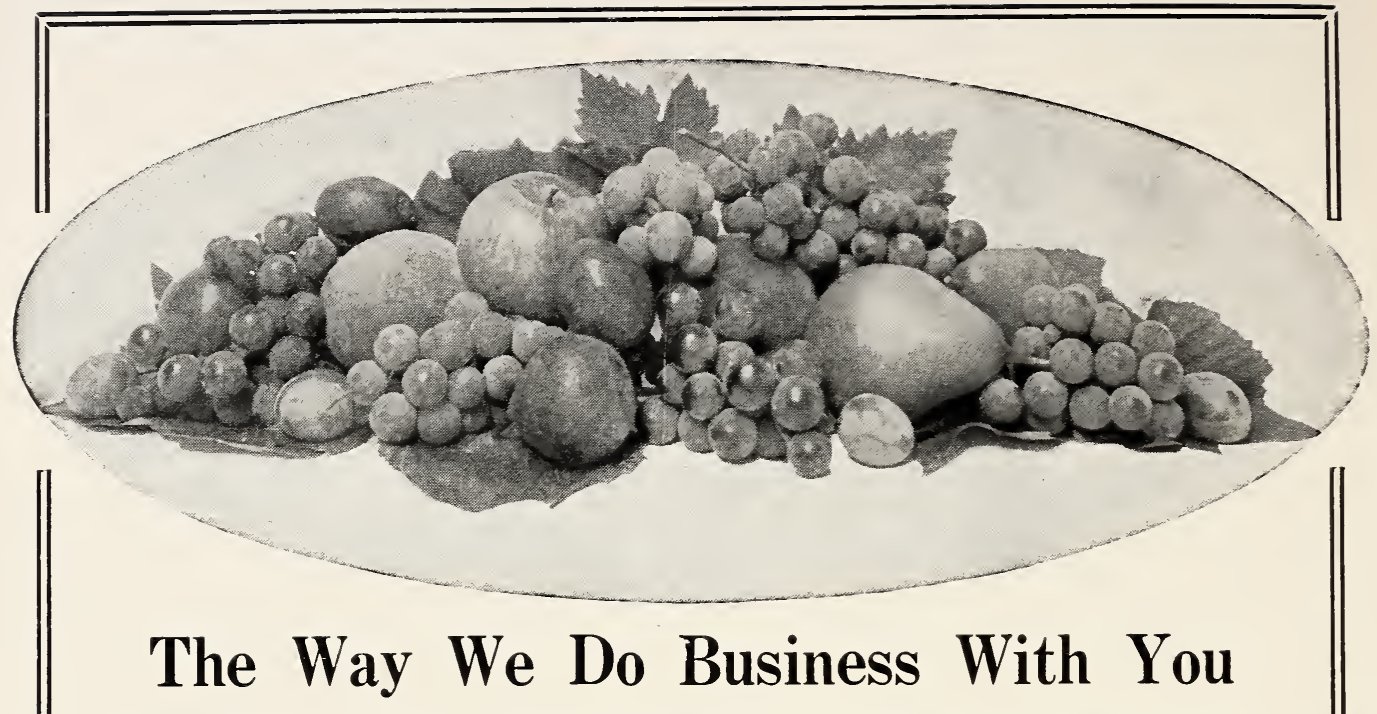

Terms Cash, unless otherwise agreed upon. All orders to be sent C. O. D. Ierms must be accompanied with one-fourth the amount in Cash. Remit by Money Order, Registered Letter, Draft or Check.

Order Farly it is important that you order early. For the benefit of cus. Order warly tomers who wish to order early, but do not care to spare all of of the amount is sent with order. We will reserve the stock for you. Balance to be sent when you order the stock shipped.

Directions for Ordering Write name and address plainly. Always state distinctly the sizes and grades of stock ordered as per the grade given in this list. When named varieties cannot be furnished, we reserve the right to substitute such varieties as will fill the season as near as possible, unless prohibited in the order. Persons unacquainted with the different varieties will generally get a much better selection by leaving the assortment to us. Keep a correct copy of the order, so that when the stock arrives you will know exactly whether you get what you have ordered. If we make mistakes, they are accidental, and we wish to right them.

Prices The prices are for the quantities named, but five, fifty and five hunPrices dred will be supplied at ten, hundred and thousand rates respectivelyi. e., five at half the price of ten; fifty at half the price of one hundred, and so on.

Packing All goods are packed free. Notwithstanding this fact, we use the best interest. Everything is correctly labeled.

Our Guarantee The fact that nurserymen, planters and fruit growers of the country have ordered of us year after year, is as good a guarantee as can be given by any other nursery of fifty years' standing. But if any mistakes occur we will cheerfully rectify them.

True to Name We use the greatest care possible to have our stock true I rue to Name to name, and should any not prove true, we stand ready to replace it free of charge, or to refund the purchase money, but do not hold ourselves liable for any greater amount than the first cost of stock that may prove not true.

All shipments of trees will be accompanied by Certificate of Inspection of the State or Government Entomologist. Good stock, true to name, sold direct to the planter at reasonable prices is our aim.

Our Location Our location is the very best for producing well ripened ments are first-class.

We solicit correspondence and personal inspection of our stock, confident that it will compare favorably with the best.

N E W H A V E N N U R S E R I E S

J. BAGBY \& SONS CO.

New Haven, Missouri 


\section{JUST ABOUT OURSELVES}

A

LL OF THE TREES we offer are grown right here on our own land and under our own care. We are proud of our record of the orchards that are growing in every state from the trees we have produced. Some of our customers have been with us for more than forty years, and we expect to keep right on serving a larger circle of new customers every year with Bagby quality trees. We make no claims at listing a great number of varieties of every kind of fruit. Neither do we aim to set forth in glowing language the supposed merits of new and untried sorts. This little catalogue contains only the standard, time-tried and tested varieties, with the descriptions written as accurately and as conscien. tiously as we know how.

Fifty years of experience in the nursery business has taught us that our cus. tomers like our way of doing business, for they know that we do not exaggerate the merits of our varieties. We produce good stock, true to name, pack it well, ship it promptly and in good condition, and charge only reasonable prices. Let us fill your order.

\section{"What Shall I Plant?"}

We wish to say that the small-size trees are strictly first-class and well-rooted, and by many will be preferred to the largel ones. So many ask, "What should I plant in my locality?" that we will here name a few of the popular and profitable sorts for general planting.

\section{APPLES}

Jonathan, Delicious, Mammoth Black Twig, Gano, York Imperial, Winter Banana, Stayman Winesap, Rome Beauty, Winesap, Grimes' Golden, Maiden Blush, Yellow Transparent. This is our Commercia List. Others would add, perhaps, Ben Davis, Arkansas Black, Missouri Pippin, Duchess of Oldenberg, eto. All of the above are good, profitable sorts, both for home use and market.

\section{PEACHES}

If you want to market your fruit, avoid planting too many early sorts. Elberta, J. H. Hale, Carman, Cap. tain Ede, Crosby, Heath Cling, Chair's Choice, Gold Dust, Belle Ga. and Crawford are all profitable for market. Should early sorts be desired, Mayflower, Greensboro, Alexander and Sneed are what you should plant. Plant October Beauty for best late yellow cling. If for home use, plant general assortment, including above, for a succession. The peach tree should have shoots and branches shortened every year or two. The land should be kept in a high state of cultivation.

\section{PEARS}

The fact is more and more apparent that Kieffer and Garber will stay in the lead for profit in the Mississippi Valley states. Duchess, Bartlett, Winter Nelis and Anjou can be profitably planted farther west. Koonce is the best early Pear.

\section{CHERRIES}

Early Richmond, Dyehouse, Montmorency, Wragg (Sour), Governor Wood, Elton and Magann (Sweet) do very well and are profitable. For general planting we do not recommend the English Morello.

\section{PLUMS}

Wild Goose (Native), Common Damson, Shrop Dam. son, German Prune (European), Abundance, Wickson and Burbank (Japanese), are all good bearers and profitable. We consider the Abundance, Wickson and Burbank the best of the well-known Japanese sorts. BLACK BEAUTY IS THE BEST OF ALL.

\section{WHOLE ROOT TREES}

All our Apple, Pear, Peach, Plum and Cherry trees are grown on "whole roots." Our Apples are grafted and planted so that the scion also roots. Don't pay extra prices for "trade marks." We give our custom er the very best, and we don't ask two prices. A trial order will convince you. In planting our trees, you set the best that experienced and skilled labor can produce.

\section{OUR SHIPMENTS}

Our shipments for Spring 1921, and Fall 1921, con sisted of over one million fruit trees, which went to thirty-seven states and territories. A total of about thirty furniture car loads. We are now growing on our premises over one million fruit trees, all clean and healthy; nothing over two years from bud or graft. We do not claim you should plant "Bagby. grown or none at all," but we do want to impress on you the fact that there are NONE BETTER.

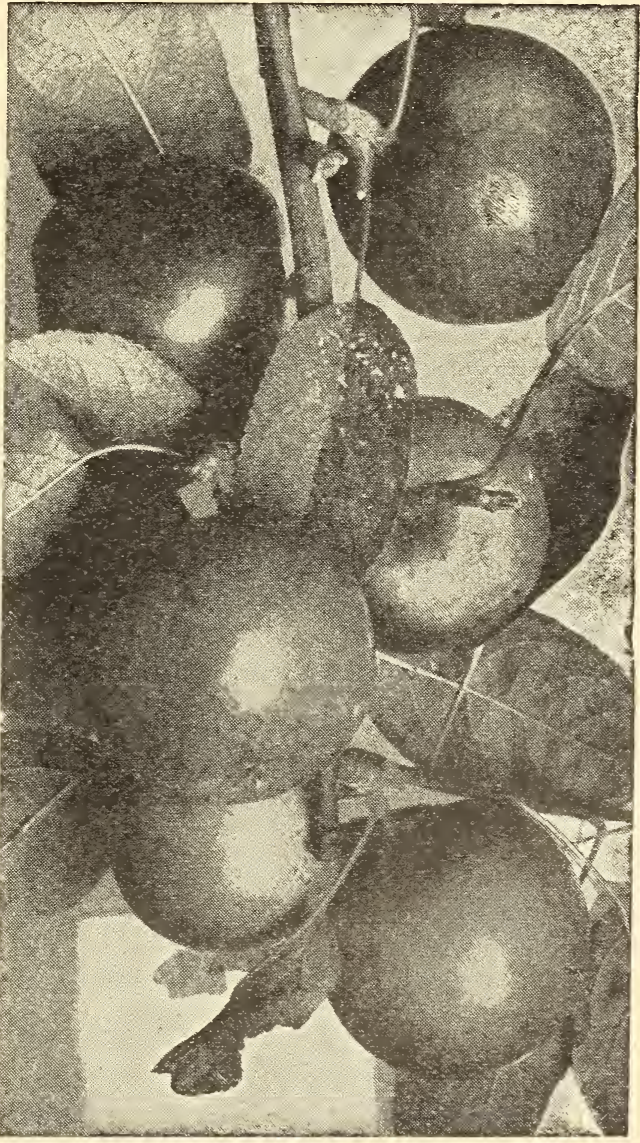




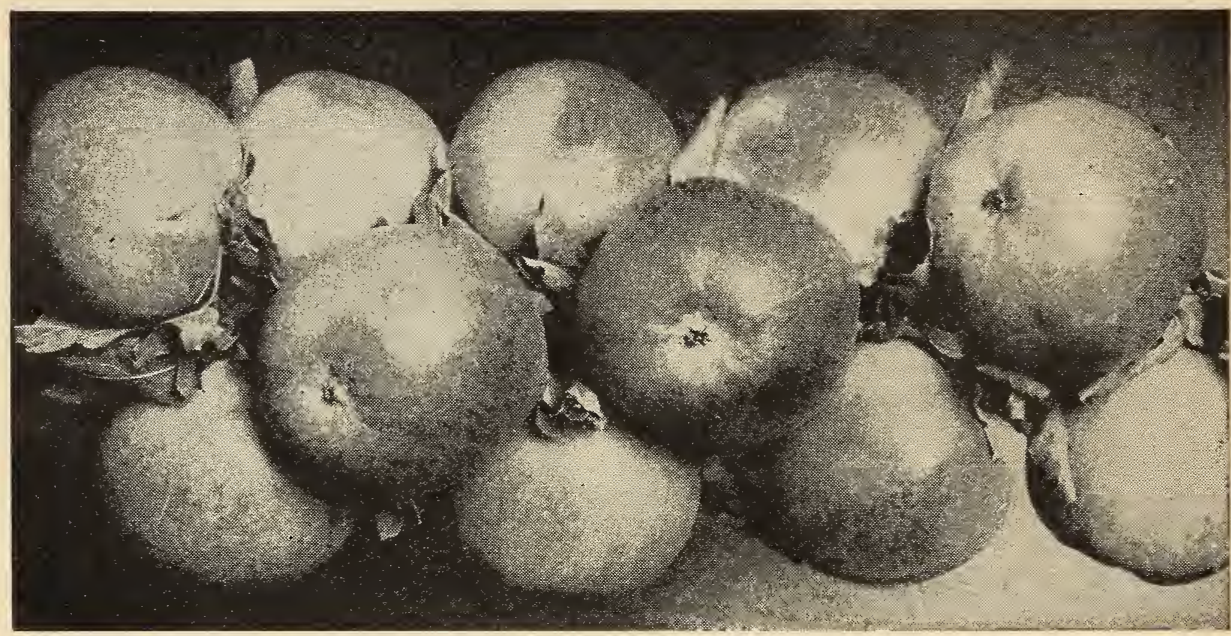

\section{Apples}

The first fruit, both in importance and general culture, is the Apple. Its period, unlike that of all other fruits, extends nearly or quite through the year. By planting judicious selections of summer, fall and winter sorts, a constant succession of this most desirable fruit will be obtained. Apple planting can never be overdone.

Our apples are all grown on Missouri river upland, on well-branched, whole roots, smooth, clean and well grown in every respect. No better trees can be found anywhere.

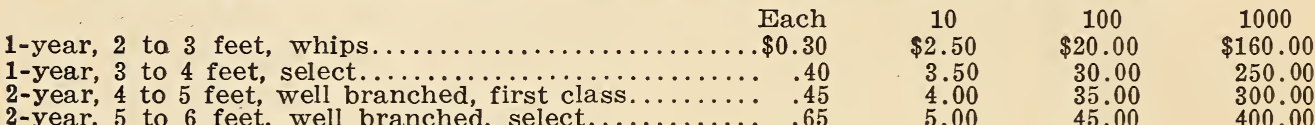

2 -year, 5 to 6 feet, well branched, select............65

\section{Summer Apples}

BENONI. One of the best summer sorts. Flesh yellow, tender, pleasant. Core small. Tree vigorous and upright.

CAROLINA RED JUNE. (Red June.) Medium size; red, flesh white; last of June. Tree is very vigorous, upright, an early and abundant bearer.

DUCHESS OF OLDENBERG (RUSsian). Medium to large size; skin yellow, streaked with red, somewhat blushed. Productive. August.

EARLY HARVEST. Medium to large, bright straw color; flesh white. Tree moderately vigorous and productive. First of July.

RED ASTRACHAN. Large, crimson, handsome; rather acid, but good and crisp; profitable. Early.

YELLOW TRANSPARENT. This valuable apple is said to be of Russian origin. We find it to be a valuable addition to our list. Medium to large; nearly white.

\section{Fall Apples}

MAIDEN'S BLUSH. Rather large, evenly shaded red cheek or blush on a clear pale yellow ground; bears large crops. August and September.

GRIMES' GOLDEN. Medium to large; rich golden yellow; flesh tneder, mild, sub-acid. Should be gathered before turning yellow and put in a cool place, and often keeps until February. Tree hardy, vigorous; an early and abundant bearer. October to Jan-

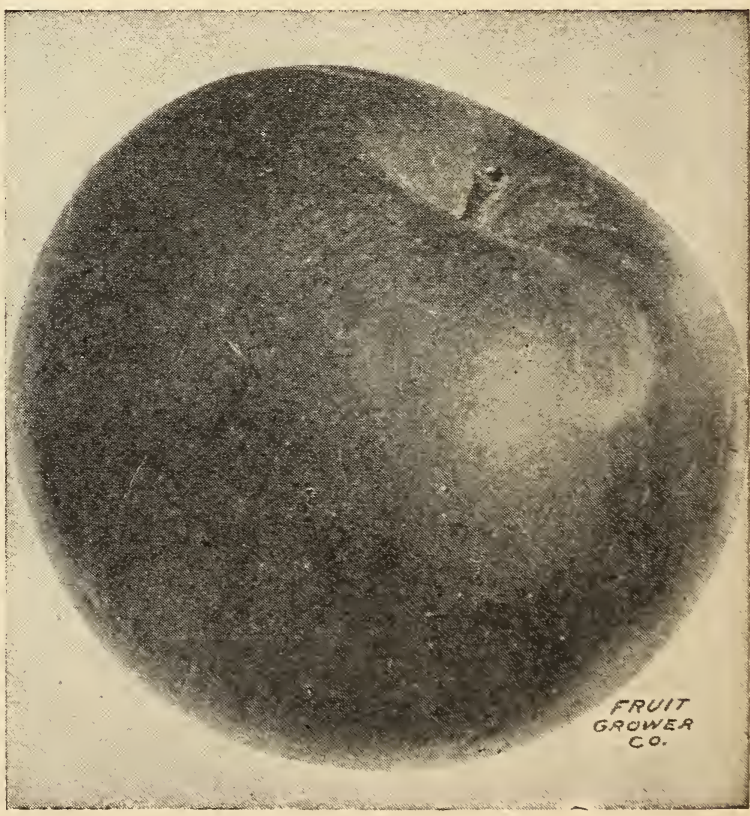
uary. 
RAMBO. Medium, streaked with dull red and somewhat dotted, productive and vigorous. Season, September to November.

WEALTHY. An apple of fine appearance and quality, an early and profuse bearer; a good market apple of its season. Tree hardy; in size and beauty it equals Baldwin, and is a better dessert apple. Ripens here in August. Winter apple North.

\section{Winter Apples}

ARKANSAS BLACK. OrIgin, Bentonville, Arkansas. The tree is a beautiful, upright grower, young wood very dark. Fruit medium to large; fine flavor; beautiful dark color, almost black; flesh yellowish, slightly subacid, crisp. One of the best cooking apples; vigorous. January to May.

BEN DAVIS. Fruit medium to large, flesh white; an excellent variety. Tree very hardy; a free grower, coming into bearing early and very productive; very popular.

December to March.

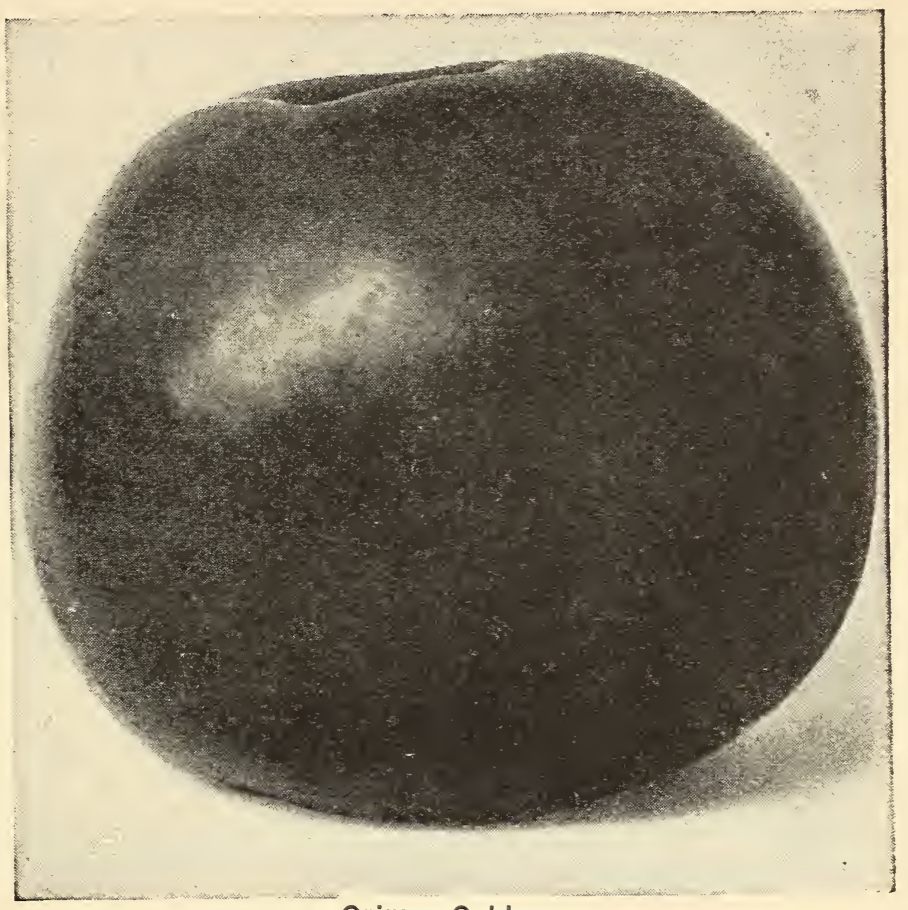

BLACK BEN DAVIS. Ben Davis type. Dark red color.

DELICIOUS. A remarkably popular variety in the West, and rapidly taking first rank both for commercial and home orchards In all the apple growing sections of the country. Fruit large, nearly covered with

dull dark red; fine grained, crisp, juicy; quality best; a splendid keeper and shipper; vig.orous grower.

HUNTSMAN'S FAVORITE. Originated in Johnson county, Missouri. Very large; golden yellow, with bright red cheek; nearly sweet, fine flavor, very aromatic. One of the best and highest selling market

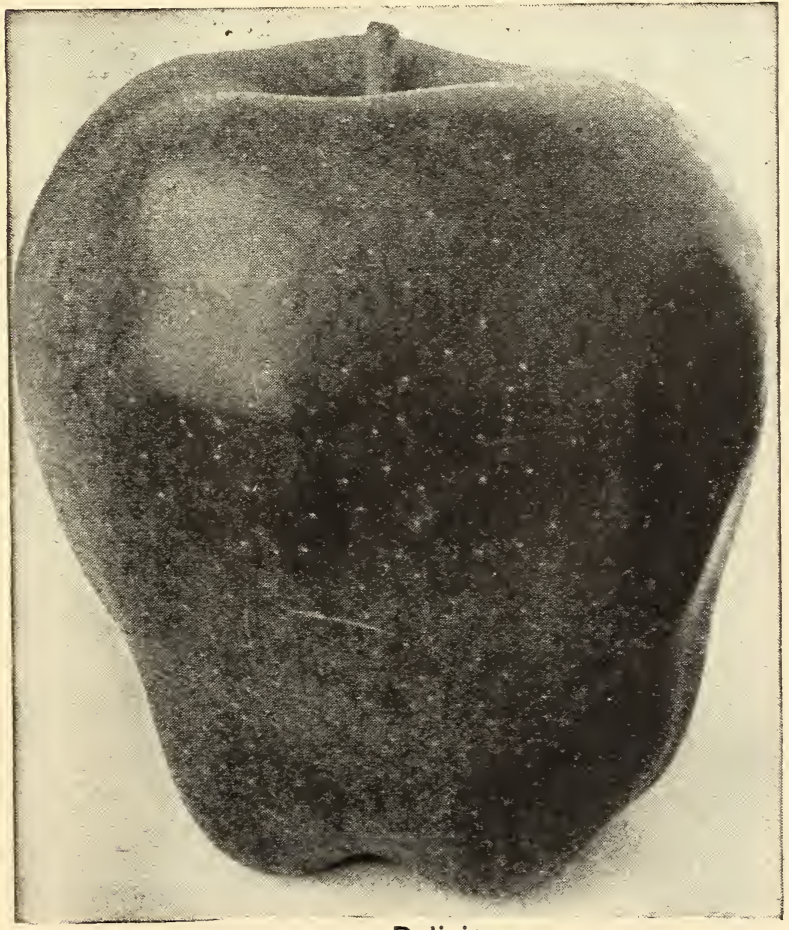
apples; tree very healthy and productive. November to January.

BALDWIN. Large, rounded; deep bright red over yellow ground; few russet dots, very productive. A great market variety. Very popular. November to February.

GANO. This apple was introduced to the public in 1886. Tree very hardy; it bears very young. Fruit bright red on yellow ground. no stripes; large; oblong, tapering to the eye; surface smooth, takes a very high polish, making it valuable as a stand fruit; flesh white. Annual, early, prolific bearer.

INGRAM. A seedling of the old Janet. Originated near springfield, Mo. Its habits are similar to the Janet, but the tree is a more upright grower and the apple is not subject to crack. Size medium; striped bright red in the sun; flesh greenish-yellow, agreeable, subacid flavor; a good keeper. Tree hardy, late bloomer; very productive.

JANET (Rawle's Janet). Medium, roundish, greenish-yellow, striped with red; rich and juicy, one of the best and longest keepers in the South and Southwest; valuable for its high quality and its late bloom ing: moderate grower. January to March. 
WINESAP. Me di $\mathrm{um}$.

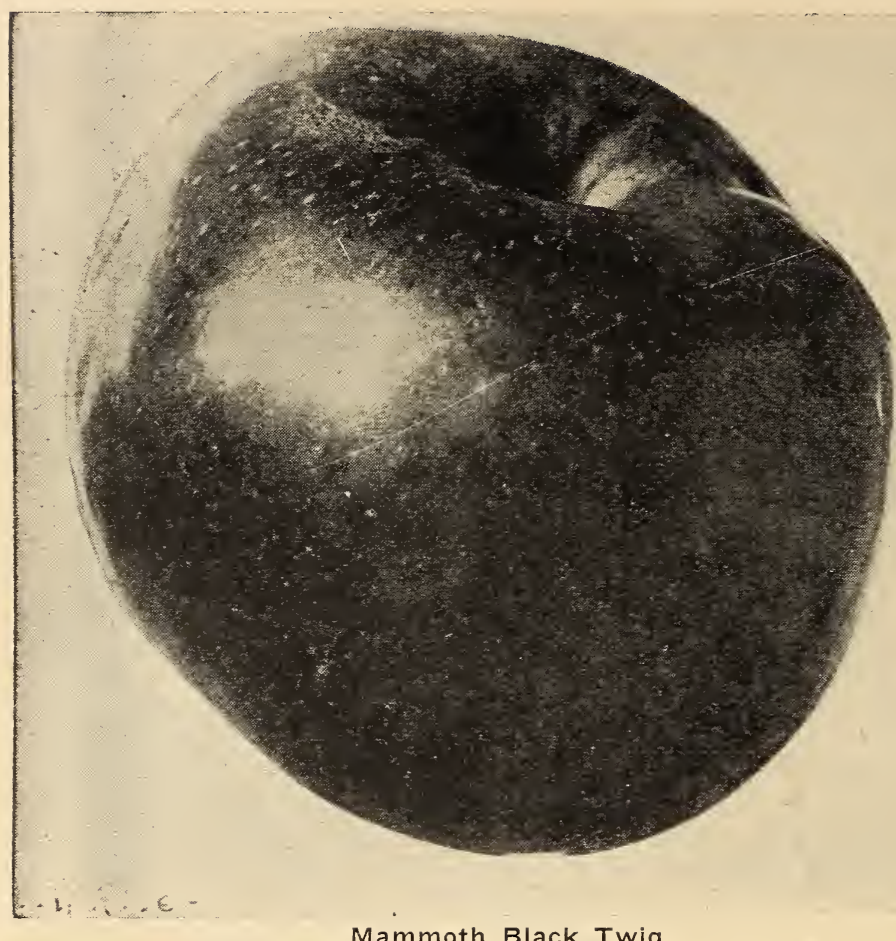

Mammoth Black Twig

JONATHAN. Fruit medium, roundish; skin yellow, nearly covered with dark or lively red; moderate grower. One of the best apples for home use or market, as it is a delicious dessert apple that always commands the highest market prices. October to January.

MAMMOTH BLACK TWIG. Supposed to be a seedling of the Winesap, but tree a better grower in the nursery and fruit much larger; or, in other words, an improved winesap. Tree a fine, upright spreading grower.

MISSOURI PIPP|N. Large, oblong, bright red with numerous gray dots; very handsome, fair quality, an early and very abundant bearer, and very profitable. December to March.

MINKLER. Bright red cheek. One of the very best late keepers. Seedling of Little Red Romanite.

ROME BEAUTY. Large, yellow shaded with red; tender, juicy, sub-acid. October to February.

STAYMAN WINESAP. Not quite so well colored as Winesap, but larger; a good keeper. Valuable for market or home use. A vigorous grower and adapts itself readily to different soils and conditions. dark red; a favorite market variety in the West. November to April.

WOLF RIVER. Very l a rge and handsome; flesh whitish, sub-acid. good bearer. Very hand. some and showy. November and December.

WINTER B A N A N A. Fancy market fruit; large. pale yellow, pink blush Tree a strong grower.

YORK IMPERIAL. This apple has been gaining favor, and is being planted largely in the West as a commercial sort. Large, smooth, yellow, shaded red, with indistinct red stripes.

\section{Crab Apples}

TRANSCENDENT. Remarkably vigorous, growing to a good size, and immensely productive. Bears a little the second year from planting, and every year after, and produces good crops by the fourth year. The best of its class for cooking and eating; juicy and crisp. Skin yellow, striped with red. September to October.

WHITNEY. Large, averaging $1 \frac{1}{2}$ to 2 in. in diameter; skin smooth, glossy green, splashed with carmine; flesh firm, juicy and rich. Very hardy; vigorous, handsome.

Prices for Crap Apples are the same as for other Apples.

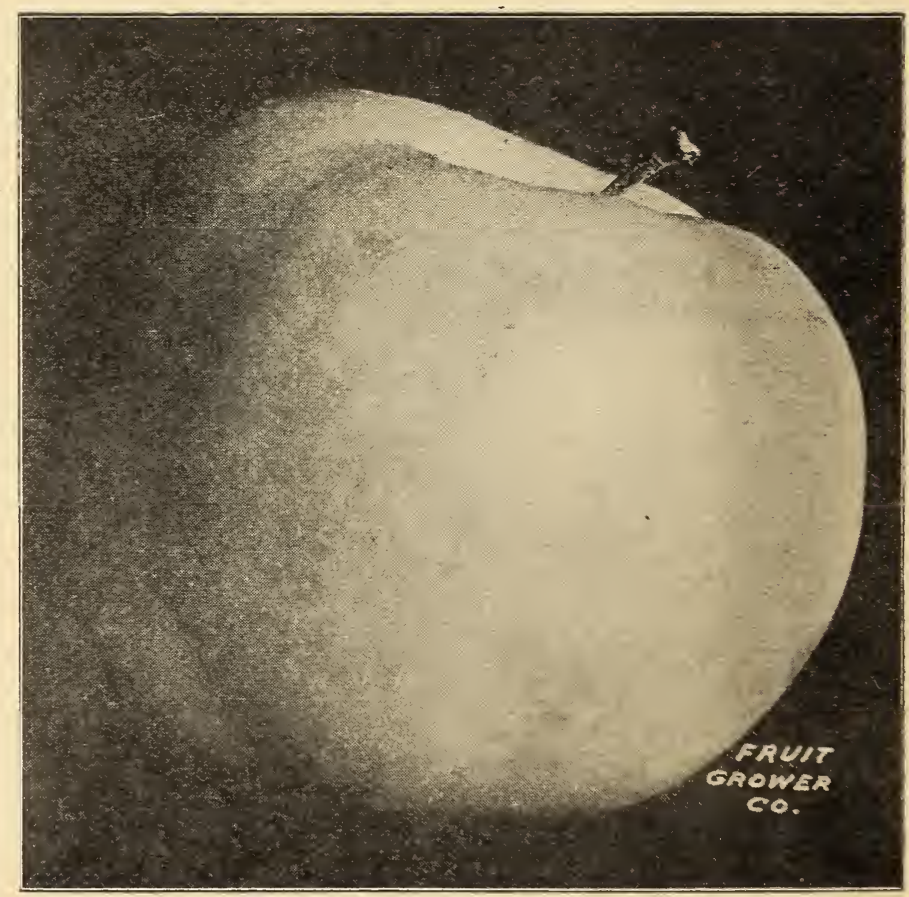




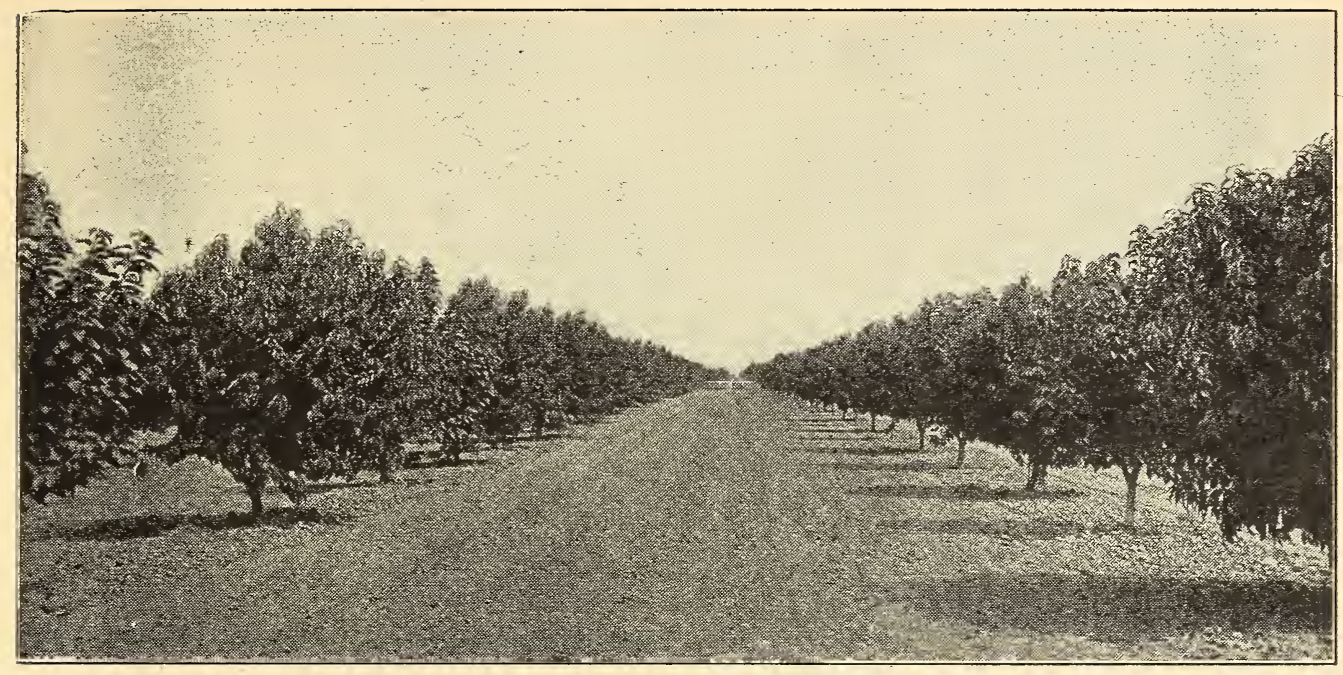

A Money-Making Orchard

\section{Peaches}

We are "Headquarters" for True to Name Peach Trees in the West, and can supply In any quantity-the best up-to-date market sorts. Our Peaches are stocky, nicely headed, smooth, straight bodies, well rooted, on healthy peach stocks and free from any disease. Remember this in comparing prices with other establishments. Over 150,000 sold and shipped to other nurserymen in 1921.

\begin{tabular}{rrrr} 
Each & 10 & 100 & \multicolumn{1}{c}{1000} \\
$\$ 0.20$ & $\$ 1.80$ & $\$ 15.00$ & $\$ 120.00$ \\
.25 & 2.25 & 20.00 & 180.00 \\
.$\quad .40$ & 3.50 & 26.00 & 220.00 \\
.$\quad .50$ & 4.00 & 35.00 & 300.00
\end{tabular}

ALEXANDER. Large size, handsome and regular in form, with deep maroon shade; adheres to stone; should remain on the tree until fully ripe. White flesh. Early in July.
BELLE OF GEORGIA. Very large; skin white with red cheek; flesh white, firm and of excellent flavor. Tree a rapid grower, very prolific; fine shipper. Ripens with Early Crawford.

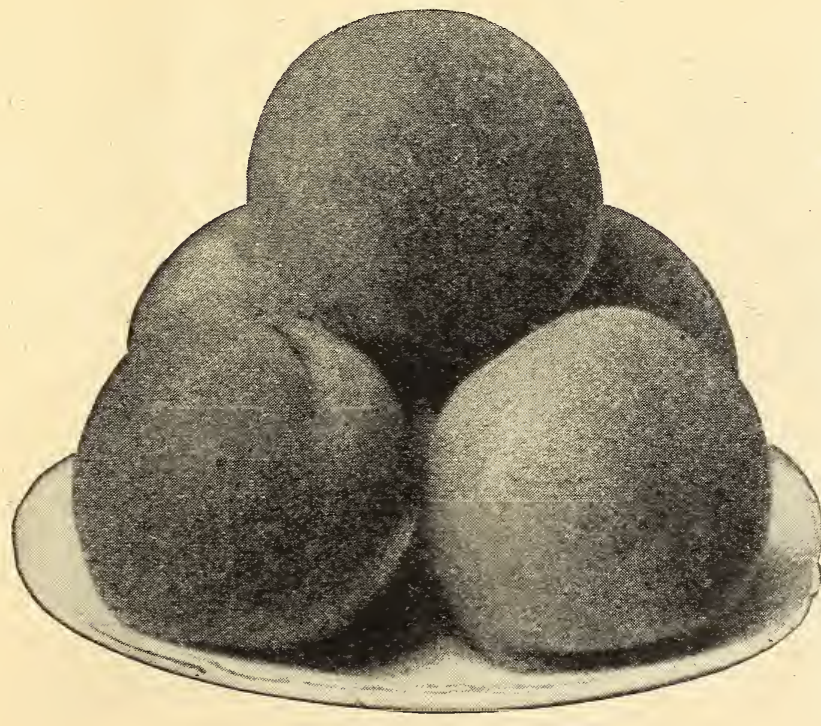

CARMAN. White flesh, large. with beautifully mottled red cheek. A valuable home or market sort. Season about fourteen days later than Alexander and about three weeks earlier than Elberta. Our stock came from the originator, and is true to name.

CHAMPION. Originated at Nokomis, Illinois. Fruit large, beautiful in appearance; flavor delicious, sweet, rich and juicy; skin creamywhite, with red cheek; freestone. August 15.

CHINESE CLING. The most popular Southern peach; shape is oblong, has creamy skin with faint flashes of red. August.

CRAWFORD'S EARLY. This beautiful yellow peach is highly esteemed for market purposes. Fruit very large, oblong, skin yellow, with fine red cheek; flesh yellow, juicy, sweet and excellent; free. Last of July. 
CRAWFORD'S LATE. Fruit of the largest size; skin yellow, or greenishyellow, with dull red cheek; flesh yellow; productive; one of the best free-stones. August and September.

CHAIR'S CHOICE. Large, late, yellow. One of the best for home or market planting. September.

CROSBY. If you want peaches every year, try some Crosby. It is medium size, rich orange yellow, splashed with red, and of the best quality. Mid-season.

CAPTAIN EDE. Originated on farm of Capt. Ede in Illinois. Is a splendid yellow free-stone variety. In appearance Captain Ede is very much like Elberta, which it equals in every way, except not quite so large, but is better quality.

ELBERTA. A Georgia cross between Crawford and Chinese Cling; very large, well colored; all things considered, the finest yellow free-stone in cultivation; no one can go amiss by planting it; the fruit is perfectly free from rot, and is one of the most successful shipping varieties. August and September.

FAMILY FAVORITE. Free, seedling of Chinese Cling, of better color; large, clear, waxen complexion, with blush; prolific, firm; a valuable variety for shipping or drying. Last of July.

FOSTER. Same season as Crawford's Early; much more productive; yellow, with red cheeks; quality best; good size.

FITZGERALD. Of Crawford type. A seedling found at Oakville, Ont., where it stands the winter perfectly; is about as hardy as Elberta; quality first-class; yellow freestone, and we recommend it.

GREENSBORO. Large, oblong, greenishyellow shaded red, flesh creamy; among the best; tree vigorous, prolific; grown largely in Georgia and the South for Northern markets. Ripe June 25 th.

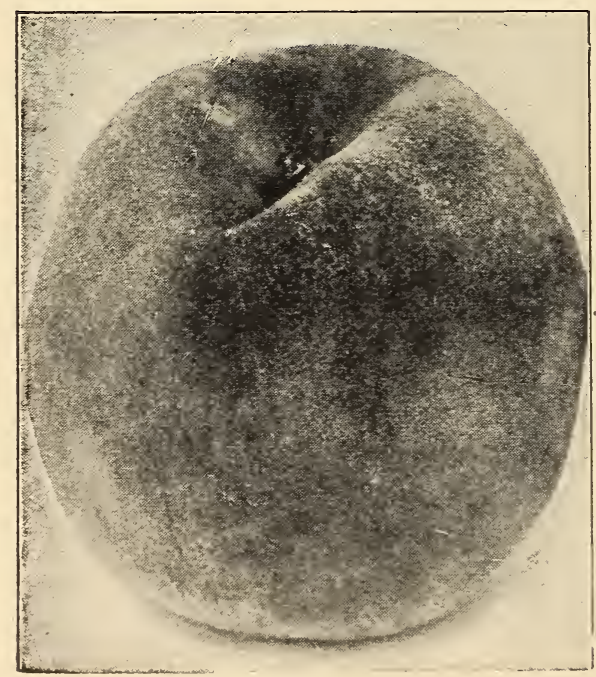

Gold Dust

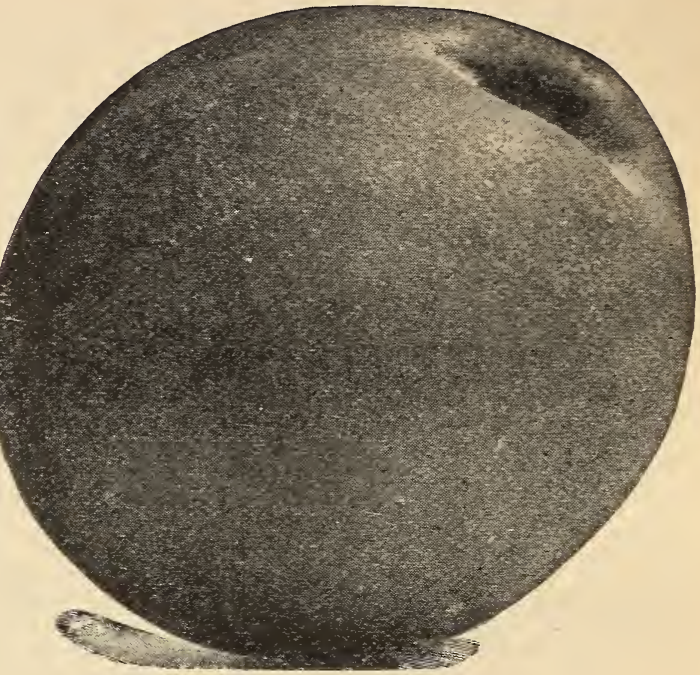

J. H. Hale

GOLD DUST. If you want the very best canning variety, this is the peach. Large yellow cling-stone; juicy, productive and of best quality. Season, September 1st to 10th.

J. H. HALE. Ripens about August 10. Yellow, finely colored; large, round, and of excellent quality. Free-stone.

HENRIETTA (Levy). Magnificent yellow cling, large size, slightly covered with bright crimson, hardy, productive, always commands fancy prices. September 25th.

HILEY. Ripens last of July. Yellowish white skin with deep red cheek. Flesh is white and very juicy. Large size. Freestone.

HEATH CLING. Large, oblong, creamy white, slightly tinged with red in the sun very tender, juicy, melting; very rich and luscious. September 15th.

KRUMMEL. Ripens September 10 to 25 Skin yellow, overlaid with crimson blush. Free-stone. The fruit is nearly round, quite large. Flesh is fine grained and has a delicious flavor. Krummel grows well in the northern and southern sections.

MOUNTAIN ROSE. Large, red; flesh white, rich, juicy, excellent. Season, August 1 st to 10 th.

MILLER CLING. An extra large clingstone. Hardy, productive, and of best quality. Earlier than Heath Cling, but larger and better color.

MAMIE ROSS. Large, white, almost covered with carmine; flesh white, juicy, and of good quality. One of the best for family use. and probably the best early commercial variety. Semi-cling.

MATTHEWS' BEAUTY. Originated in Georgia. A late yellow free-stone. Fully as large as Elberta; two weeks later. A splendid shipper.

MAYFLOWER. A beautiful "red-all-over" peach; handsome and of splendid quality. Extremely early. Tree hardy and healthy. 
OCTOBER BEAUTY. A late yellow Cling. When ripe a dark purple. Originated on the grounds of Judge Hugo Muench of St. Louis. We recommend it as the best late yellow Cling.

OLD MIXON FREE. Large, white flesh, with deep red cheek; rich and good; one of the best. August.

RINGGOLD CLING. Much larger than Heath, in every way an improvement on that popular kind. A very valuable peach. September.

SALWAY. Large, roundish, skin downy, creamy yellow, with a warm, rich, clear crimson red cheek in the sun; flesh deep yellow, stained with red at the stone; juicy, rich, very good. Free-stone. A good market sort. September 15. Hardy.

SMOCK FREE. Fruit large, skin orange yellow, mottled with red; a good market sort. One of the standard varieties. September 15. Hardy.

SNEED. Ripens earlier than Alexander, and belongs to an entirely different type; it is very distinct in tree and fruit, belonging to the Chinese Cling type; size medium; hardy.

STUMP THE WORLD. Very large; roundish; skin white, with a bright red cheek; flesh white; a free-stone. End of August.

TRIUMPH. The earliest yellow peach known; productive, hardy and profitable for market. Originated in Georgia. Hardy.

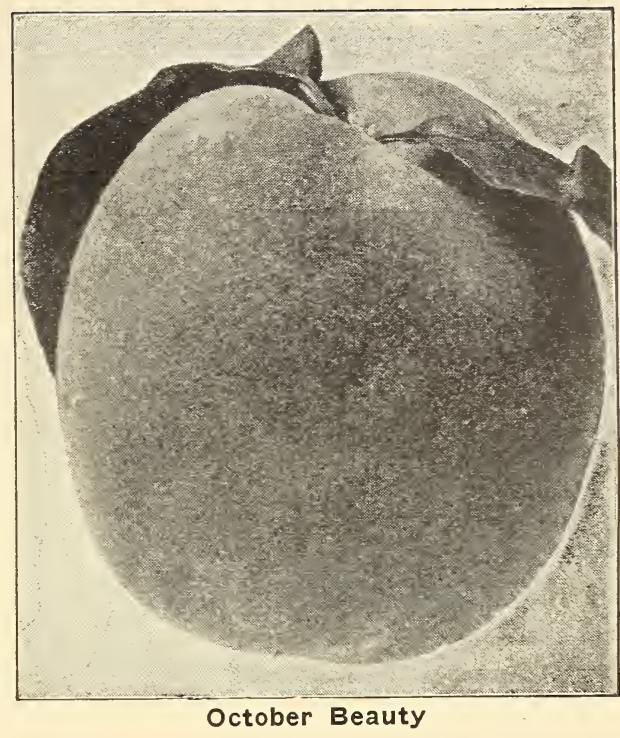

WONDERFUL. Color rich yellow; flesh yellow, highly flavored; firm. Ripens in September. Very similar to the Smock.

WHEATLAND. Large, roundish, skin golden yellow, shaded with crimson on the sunny side; flesh is yellow and of fine guality; tree vigorous grower. August. Season is just ahead of Elberta.

\section{We want all our customers to plant OCTOBER BEAUTY (Late Yellow Cling) as the LATEST and BEST. Medium size, high color and quality.}

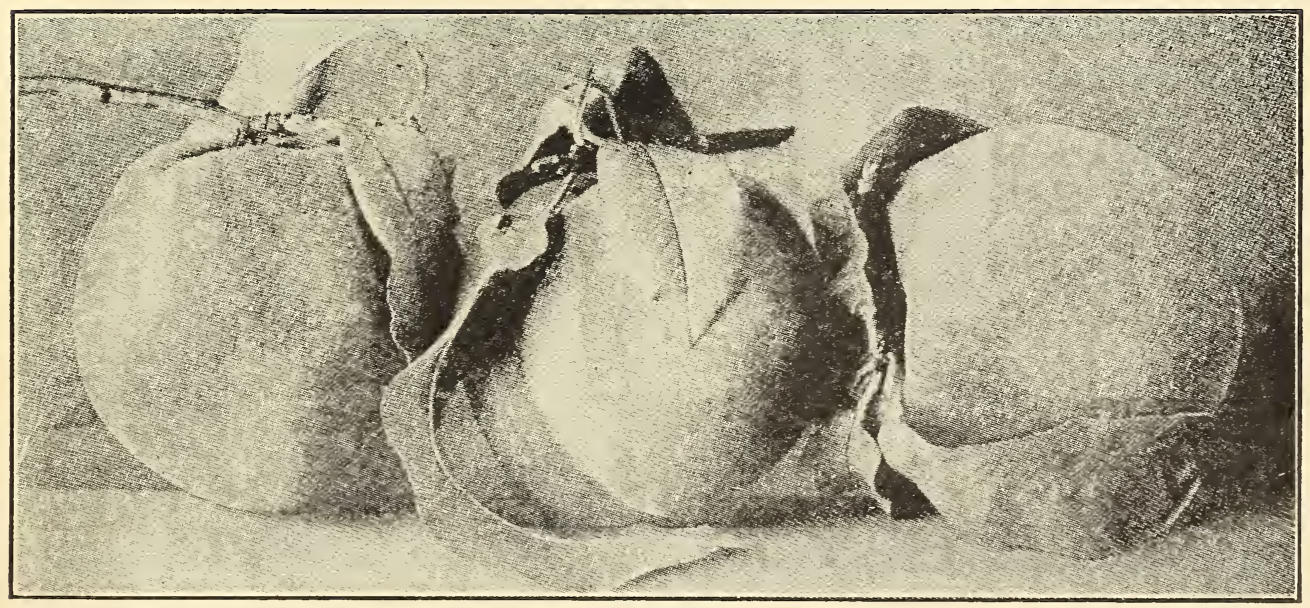




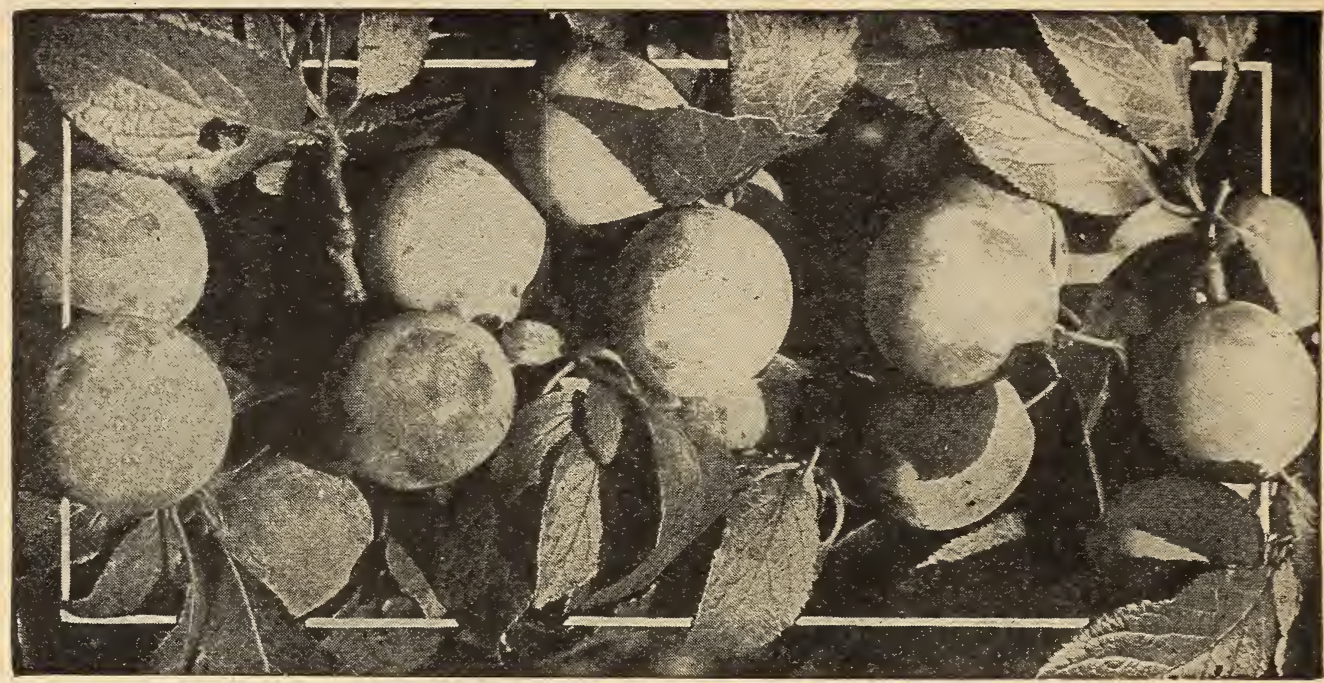

\section{Plum Trees}

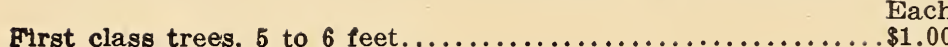

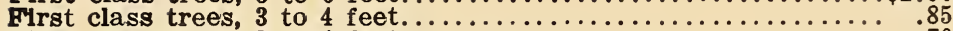

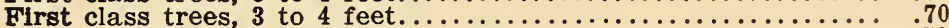

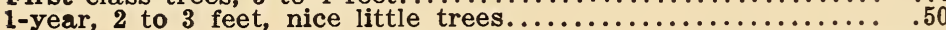

ABUNDANCE. A hardy, productive Japanese sort. Large, purplish red; quality very best. Season, early in July.

BLACK BEAUTY (New). (See illustration and further description on inside back cover.) The best Japan sort we have ever grown. Large, very dark purple, almost black. Persimmon shape. Quality and size of Abundance. 5 to 6 foot trees. $\$ 1.00$ each; $\$ 9.00$ per 10; $\$ 75.00$ per 100 .

BURBANK. Large, varying less in size than the other Japanese plums; it is nearly globular; clear cherry-red, with a thin lilac bloom; flesh deep yellow, firm and meaty; tree vigorous and productive. Last of July.

COMMON DAMSON. Wellknown and very productive. Season, September.

GERMAN PRUNE. V e r y profitable and will succeed wherever Common Damson can be grown. Very large. We consider it the best of European sorts. August and September.

LOMBARD. Medium, round, oval, violet, red; juicy, pleasant and good; adheres to the stone. Tree vigorous and productive. It is a valuable market variety; one of the most hardy and popular. August.

RED JUNE. One of the largest Japanese varieties; ripening before Abundance. Tree upright, vigorous and hardy.

SHROPSHIRE DAMSON. A plum of fine quality, sprightly. In market it has commanded nearly double the price of the common Damson; enormously productive. Last of September. tiful; flesh soft, melting, delicious, with a full, fruity flavor. Tree a strong grower, prolific.

WICKSON. We regard this as one of the best of the late ripening Japan sorts. Readily parts from the seed. Extra large. Season. August.

For the Home Orchard plant Abundance, Burbank, Black Beauty, Common and Shrop. shire Damson.

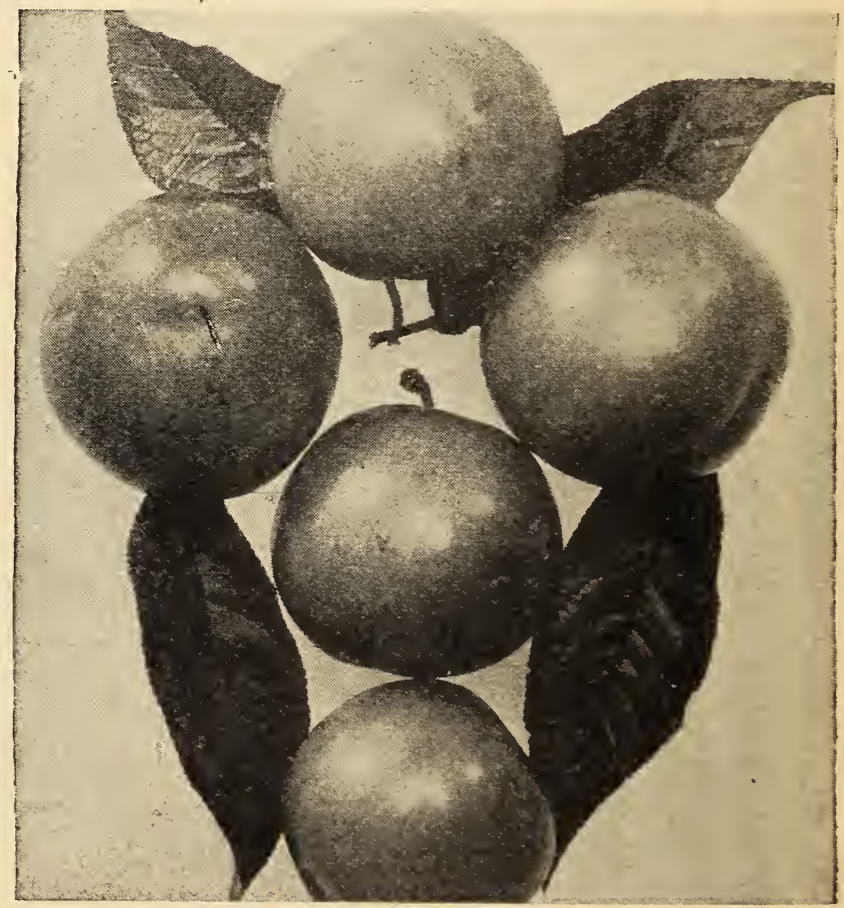

Black Beauty 


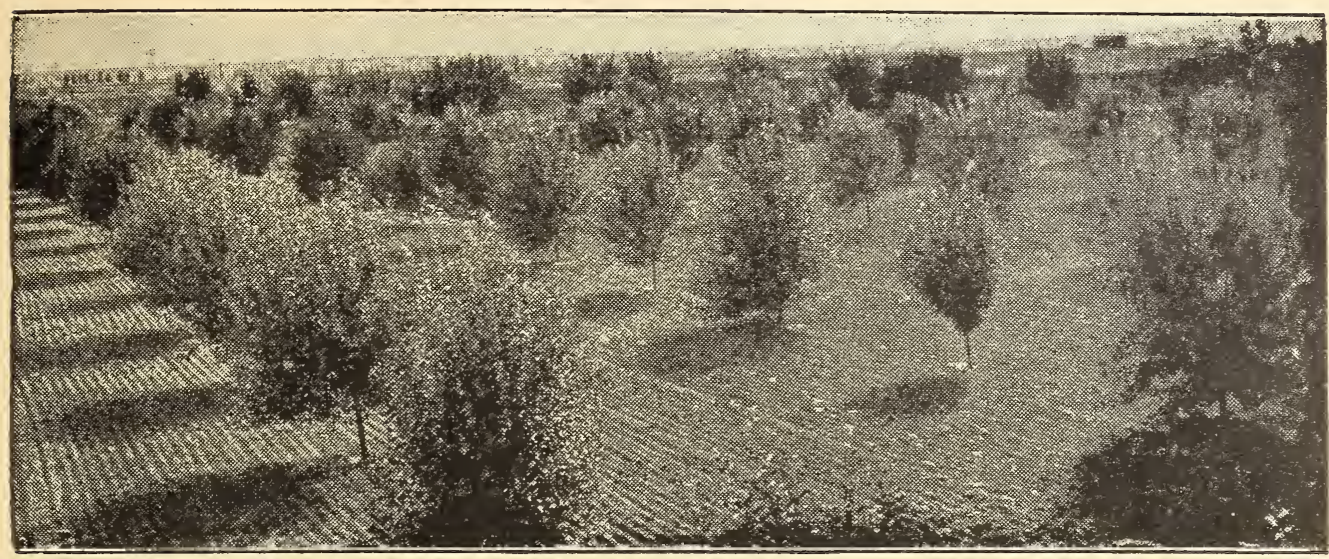

\section{Pear Trees}

Our Pears are especially clean, smooth and well rooted, grown on XX French imported stocks.

Leading sorts, first class, 5 to 7 feet, 2 -year $\quad$ Each $\quad 10 \ldots \ldots \ldots$

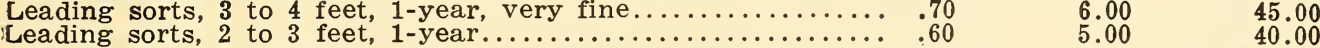

For Kieffer and Garber in quantities of 300 or more, write us for special low prices.

\section{Summer Pears}

KOONCE. The handsomest, best and most valuable; very early pear; tree vigorous, upright grower, free from blight; magnificent foliage, which it retains late in the season; iruit medium to large; skin yellow, does not rot at the core, juicy, sweet and of a delicious quality. Is an excellent shipper.
BARTLETT. Large, skin very thin, clear lemon-yellow, with soft blush on the sunny side; flesh white, buttery, very juicy and highly flavored. The best summer pear in existence for quality.

CLAPP'S FAVORITE. Large, pale lemonyellow, marbled with crimson on the sunny side and thickly sprinkled with brown dots; flesh finely grained and melting with a rich vinous flavor. August.

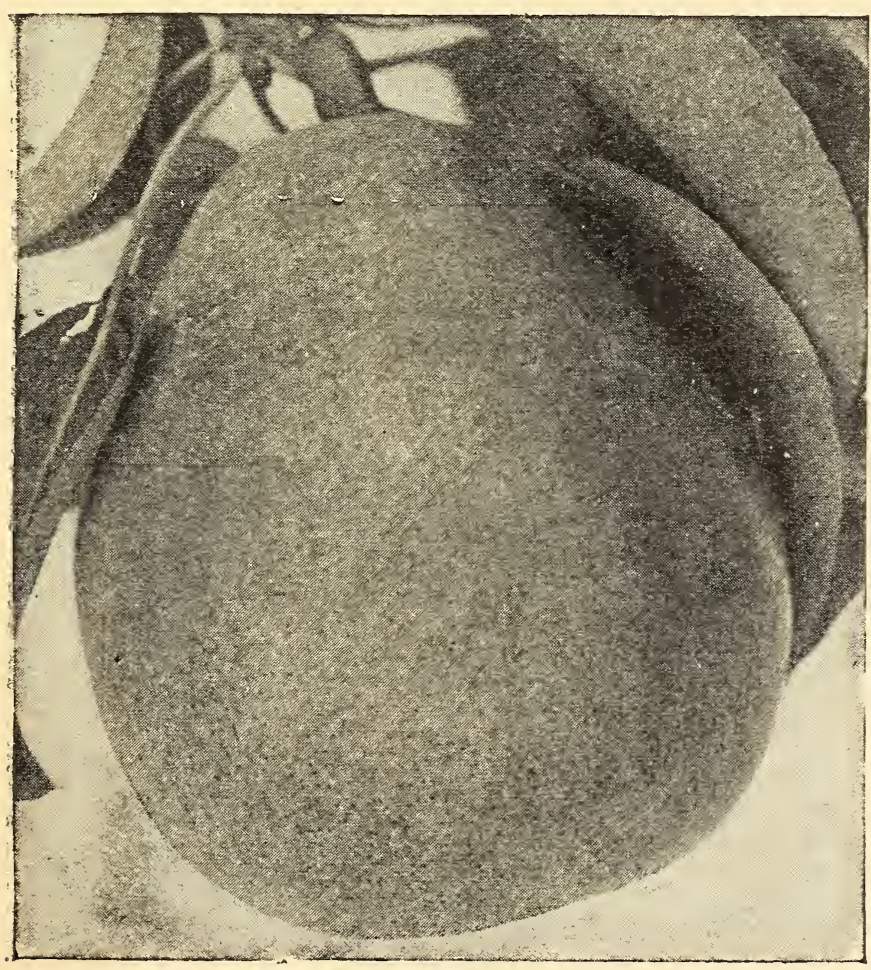

ANJOU. One of the most delicious late fall pears; juicy and of excellent quality.

\section{Autumn Pears}

DUCHESS. Very large, greenish-yellow; sometimes a little russeted; makes a beautifu] tree. One of the best. October and November.

GARBER. Originated in Pennsylvania. Fruit is large and beautiful; color bright yellow, with red; juicy and good; delicious canned. Ready to pick with LeConte, or a few days later, and much better, not only in fruit, but in hardiness and health of trees.

FLEMISH BEAUTY. Large, beautiful, juicy, melting, rich and fine; strong grower and good bearer; hardy everywhere. September and October.

KIEFFER. Tree a remarkable grower, with so vigorous a constitution that it $\mathrm{rarely}$ blights. Fruit of fine size, rich color and good quality. Brings high prices in competition with other varieties. Best when picked at maturity and houseripened. October and November. 


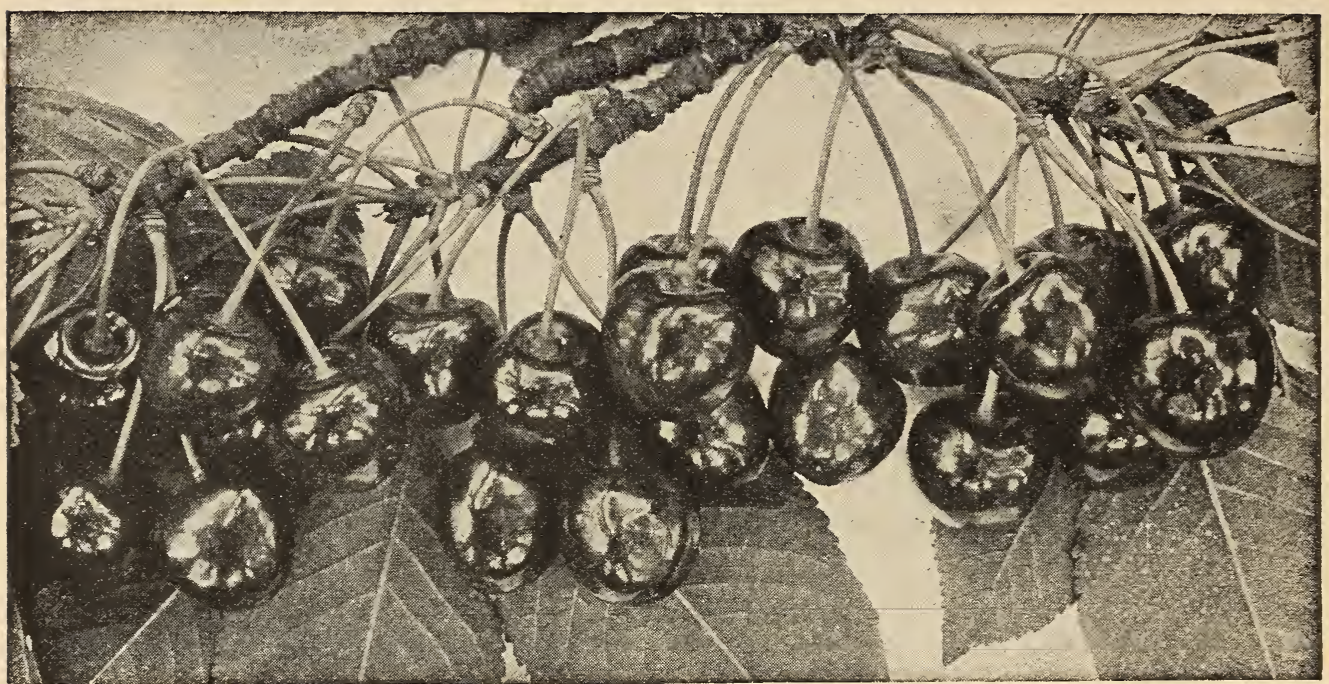

\section{Cherries}

There are few more desirable fruits than Cherries, and they can be grown for market with great profit. Along the street or avenue as ornamentals, especially the Heart and Biggarreau varieties are strong, vigorous growers, with large, glossy leaves and open. spreading heads, making a fine shade. Cherries thrive in almost any well drained soil. The fruit is equally delicious whether eaten from the tree or preserved, and it will always find a ready market at profitable prices.

Our Cherry trees are all budded on Imported French Mahaleb and Mazzard stock. They have fine roots and nice heads. All well rooted and will be graded full size indicated, and up.

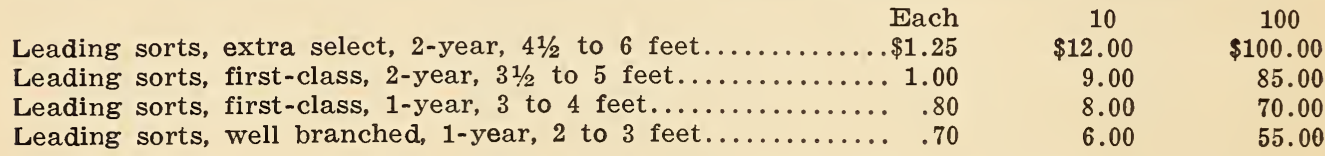

DYEHOUSE. Very early and sure bearer. Ripens before Early Richmond; but not quite as productive. May.

ENGLISH MORELLO. Medium to large, blackish-red; acid; juicy. Very productive. Short lived. July.

EARLY RICHMOND (Kentish Virginian or Early May). Medium size; red; melting, juicy, sprightly, acid flavor. This is one of the most valuable and popular of the acid cherries, and is exceedingly productive. First of June.

GOV. WOOD. One of the best sweet cherries; very large, light red, juicy, rich and delicious. Tree healthy and a great bearer. May and June.

LATE DUKE. Fruit similar to May Duke, but later and not so sweet.

MONTMORENCY. No doubt one of the finest acid cherries; tree very hardy and an immense bearer; commences to fruit while young and is loaded annually thereafter with fine crops; fruit of good size; fine flavor, and of bright clear shining red; valuable everywhere, especially for Northern latitudes; larger than Early Richmond, and fully ten days later. Season, end of June.

MAGANN CHERRY. A new sweet cherry. Fruit large, almost black when fully ripe. growing in large clusters. It will pay you to include some of these in your order for other stock.

OSTHEIMER. Largest size, very dark: flesh tender, juicy. Late June.

WRAGG. Originated in Iowa. Medium to large in size, long stem, dark purple when rully ripe. A variety well adapted for the high altitude and prairie regions of the Northwest.

For Middle West we suggest as best commercial sorts in cherry-Richmond, Montmorency, Magann. For larger as sortment include Dyehouse, Wragg, English Morello, Governor Wood. 


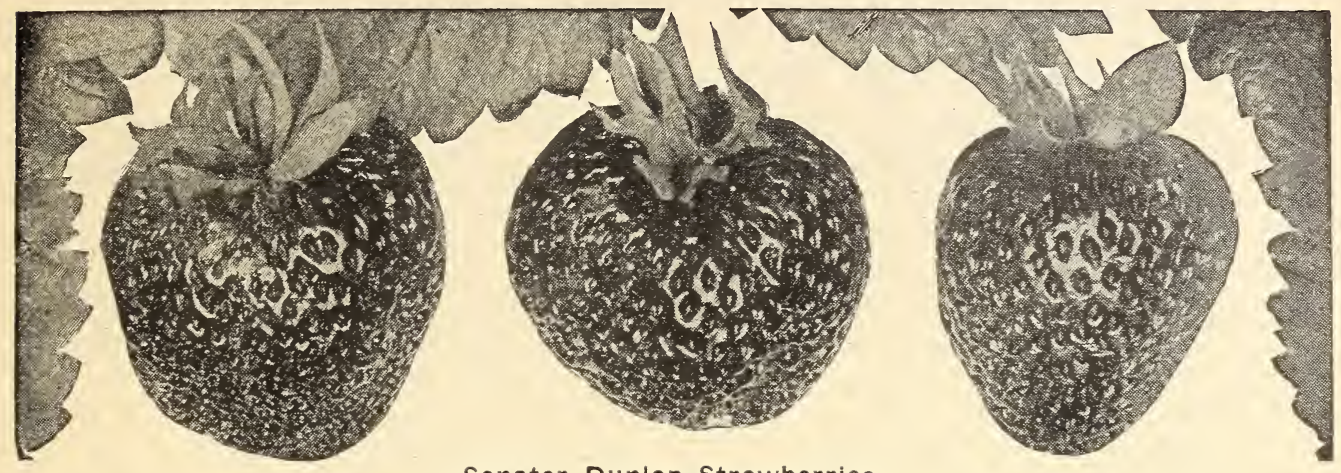

Senator Dunlap Strawberries

\section{Strawberry Plants}

Prices of Strawberry Plants, for spring shipment only: Selected plants, 25c per $10 ; \$ 1.00$ per $100 ; \$ 8.00$ per 1,000 .

Large orders must be sent by express. Small orders carry safely by mail. They do not carry well by freight.

AROMA. (Per.) Plants large, very vigorous and perfectly healthy. Makes plants just right for a good fruiting row. The blossom is rich in pollen, a good fertilizer for Sample, Bubach and Enormous. Fruit large to very large, roundish, conical, smooth and perfect in form, of a beautiful bright glossy red in color, very firm, and of excellent quality. Will give splendid results on any soil that will grow a good crop of corn or potatoes. It is nearly as late as Gandy, of long season. Three times as productive and a sure cropper every year. During the past five years the demand for plants of this variety has been very heavy and we have never been able to grow plants enough to meet this demand.
SENATOR DUNLAP. (Per.) A well-tested, wonderfully productive variety, one of the safe sorts to plant everywhere and sure to take a high place among the prominent standard sorts. Plant resembles Warfield, rampant runner, should be restricted in its production of plants; fully equal to Crescent and Warfield in its ability to succeed under all circumstances. Fruit good size, regular form, beautiful bright red, glossy, firm, splendid keeper and shipper, excellent quality. One of the best for canning; ripens early and continues a long time. It promises to stand at the head in its wonderful ability to ripen a good crop, under almost any condition of drought or neglect.

\section{PRICE LIST OF FRUIT AND ORNAMENTALS}

\section{Apricots}

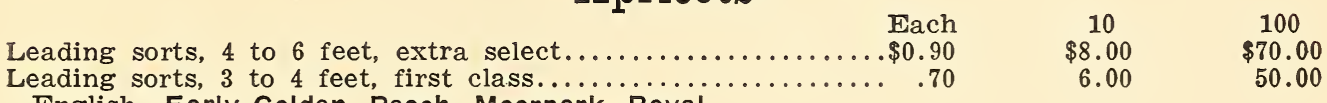

English-Early Golden, Peach, Moorpark, Royal.

Russian-Superb.

\section{Quinces}

Leading sorts, 3 to 4 feet, 2 -years, extra select...........\$0.90

Leading sorts, 2 to 3 feet, 2-years, first class............. 70

\section{Mulberries}

Each

New Everbearing (best), 4 to 6 feet.......................... $\$ 0.70$

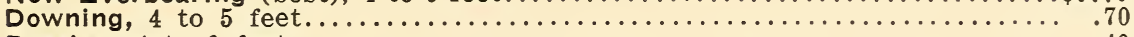

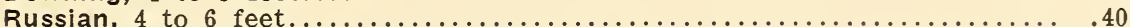

Tea's Weeping-Nothing better for lawn, 2-year heads............. 1.50

\section{Nut Trees}

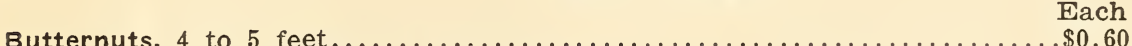

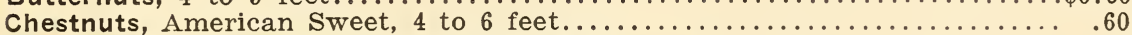

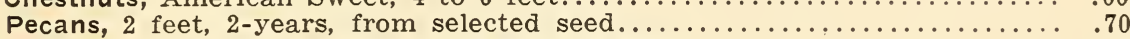

Pecans, 1 to 2 feet, 2 -years, from selected seed.....................60 


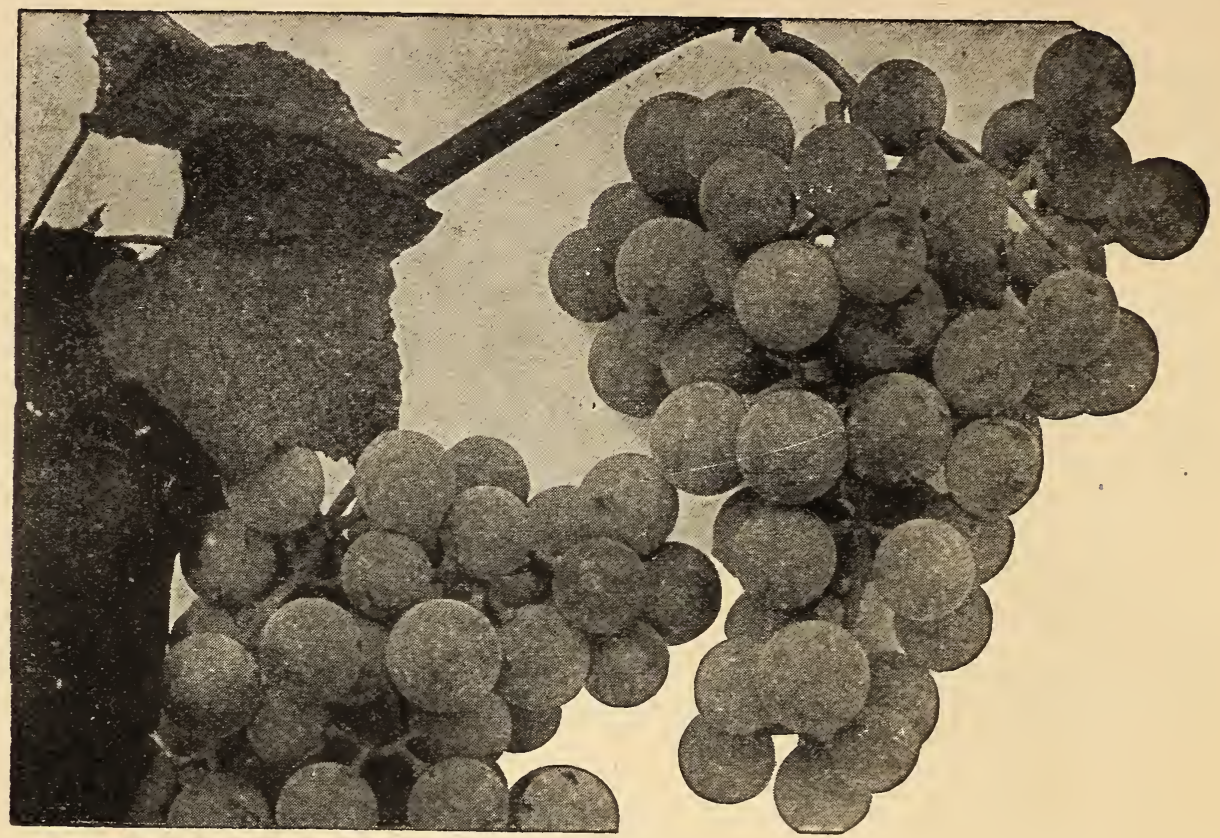

\section{Grape Vines}

\section{Each}

Catawba, 1-year, No. 1, Late Red.................. 20

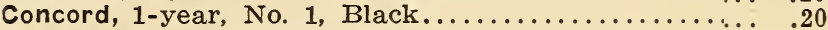

Delaware, 1-year, No. 1, Red.................. 10

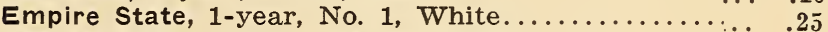

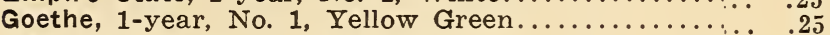

Hartford, 1-year, No. 1, Black................... 20

Ives' Seedling, 1-year, No. 1, Black............... . 20

Moore's Early, 1-year, No. 1, Black................ 30

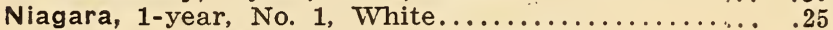

Norton's Virginia, 1-year, No. 1, Black........... .35

Pocklington, 1-year, No. 1, White Yellow.......... 25

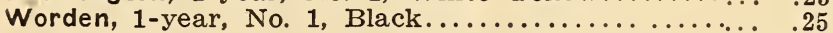

$\begin{array}{ll}10 & 100 \\ \$ 1.75 & \$ 15.00 \\ 1.75 & 12.00 \\ 1.75 & 12.00 \\ 2.00 & 15.00 \\ 2.00 & 18.00 \\ 2.00 & 18.00 \\ 1.75 & 15.00 \\ 1.75 & 15.00 \\ 2.50 & 20.00 \\ 2.00 & 18.00 \\ 3.00 & 28.00 \\ 2.00 & 18.00 \\ 2.00 & 15.00\end{array}$

\section{Raspberries}

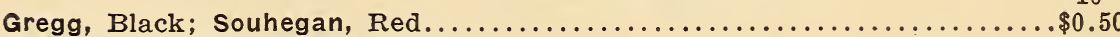

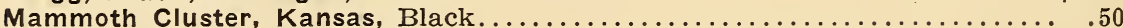

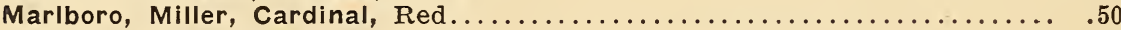

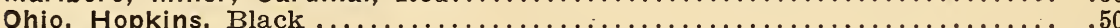

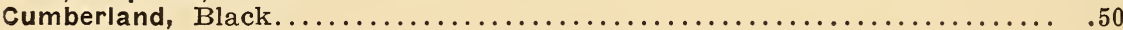

\section{Blackberries}

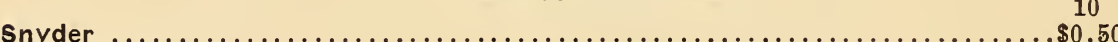

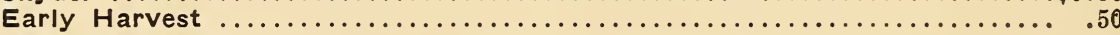

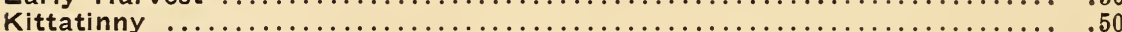

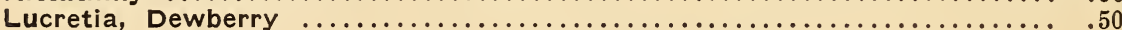

\section{Currants}

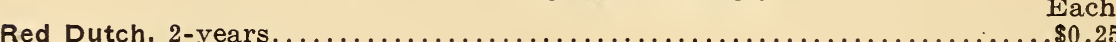

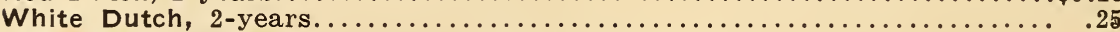

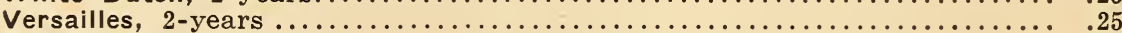

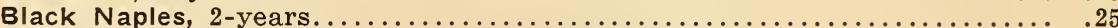

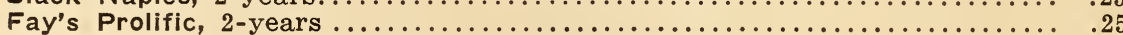

\section{Gooseberries}

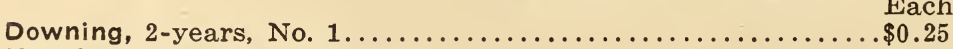

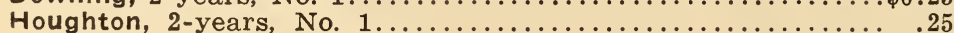




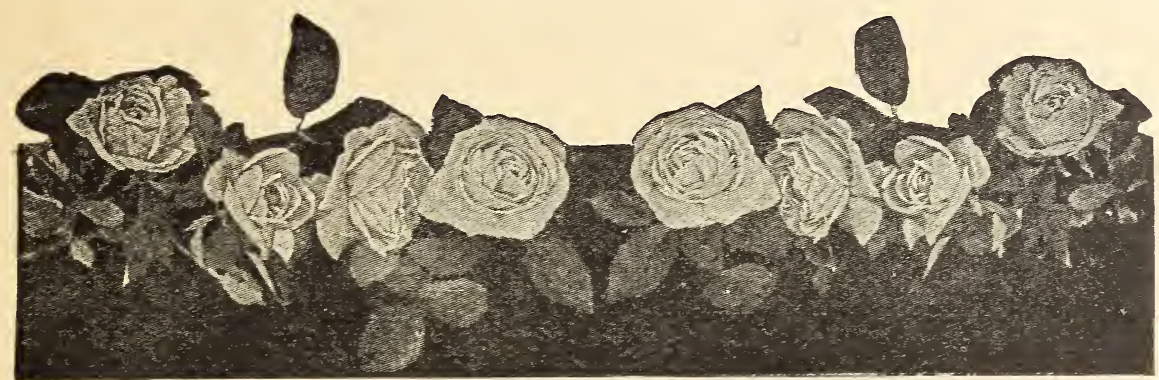

Roses

Hybrid Perpetuals and Teas, 2-years, extra........... $\$$ Each

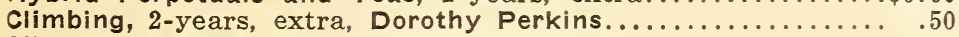

Climbing, 2-years, extra, Crimson Rambler............... .50

Baby Ramblers, 2-years and extra, 1-year, white, pink and red .50

$\begin{array}{cc}10 & 100 \\ \$ 5.00 & \$ 45.00 \\ 4.00 & 35.00 \\ 4.00 & 35.00 \\ 4.00 & 35.00\end{array}$

\section{Ornamentals}

California Privet, 2-years, No. 1, 2 to $3 \mathrm{ft}$., extra heavy......\$0.10

California Privet, 1-year, No. 1,12 to 24 in., first class....... 08

Calycanthus, 2 to 3 feet, first class..................... 30

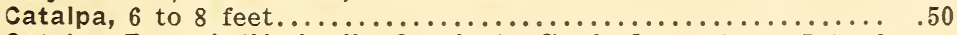

Catalpa Bungei (Umbrella Catalpa)-Grafted on stems 5 to 6

feet high, it makes an umbrella-shaped top without prun-

ing. Perfectly hardy, and flourishes in all soils and

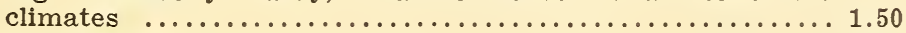

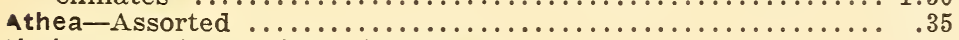

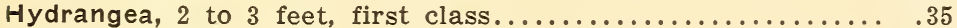

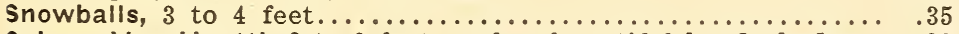

Spirea, Van Houtti, 2 to 3 feet, makes beautiful hardy hedge.. . 30

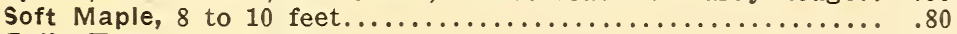

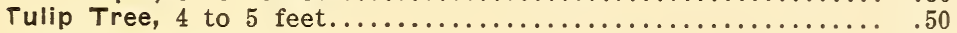

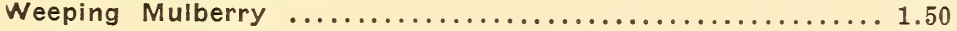

\section{Rhubarb}

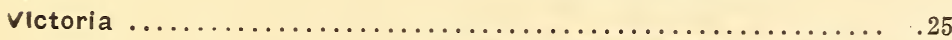

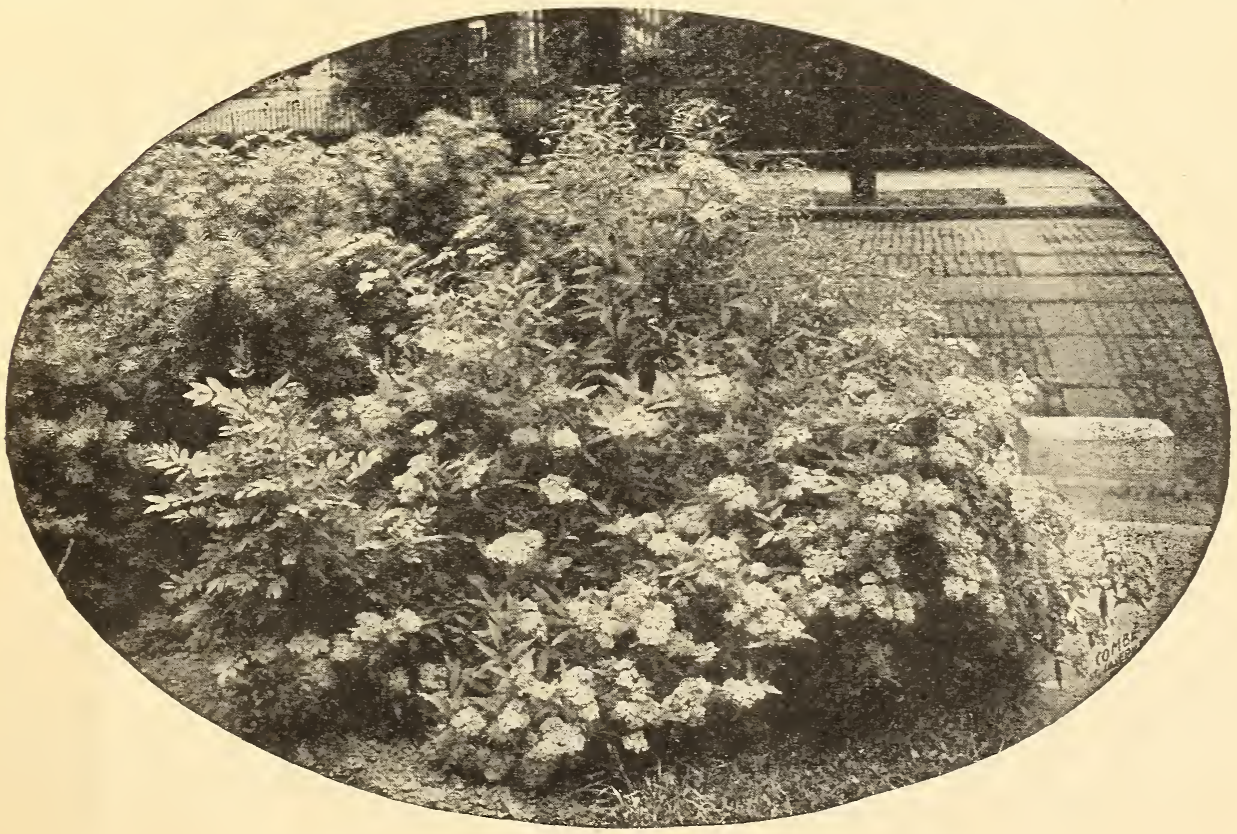




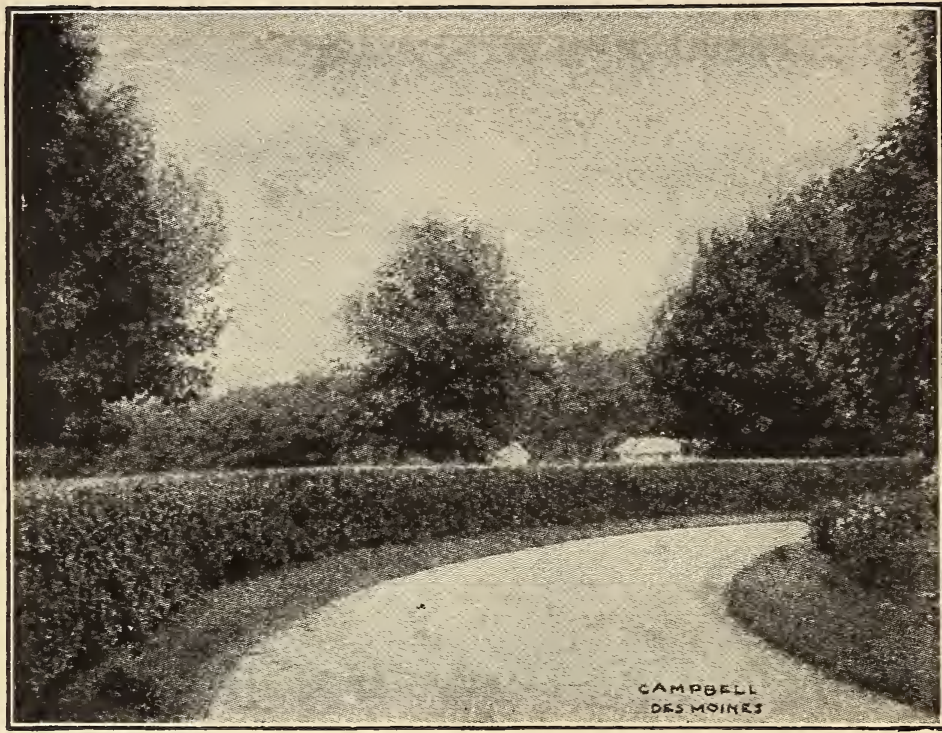

California Privet

\section{General Information}

Fifty years have been spent in building up our nursery business here at New Haven. It was established in 1872 by Julian Bagby, the father of the present management In 1892, the business was incorporated and since that date has been under the management of R. J. and J. L. Bagby, ably assisted by men in our employ. These employees have grown up in the business and are honored citizens in the community. We state this fact that our customers may know that their orders are handled by responsible men.

We own over four hundred acres of land, on which we grow our trees. This land has a value of over fifty thousand dollars. This information is given that you may know that we are responsible. We want you to feel as safe in dealing with us as you do with your bank.

\section{About Agents}

We are not employing traveling salesmen to solicit orders, but we shall be pleased to have you get a club among your neighbors, and on club orders amounting to $\$ 100.00$ or more, at single, ten or hundred rates, we allow you 10 per cent additional in stock. We put up each order in a separate package, so that upon receipt of the goods you have only to hand out the different lots as ordered. Many of our best customers buy in large quantities at the lowest rates and distribute in lots as ordered by their neighbors.

We also desire to sell to nurserymen and dealers who buy to sell again, and special prices will be made on carloads or larger quantities than indicated in this list.

\section{References}

Some of our correspondents have asked us to give them bank references, and we hereby comply, and refer to local banks and to the commercial agencies. We do our local business with Farmers' Savings Bank, New Haven, Mo.

\section{Distances for Planting}

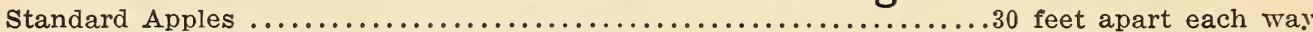
Standard Pears and Strong-growing Cherries................... fe feet apart each way

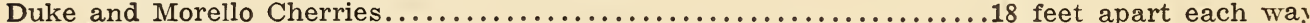

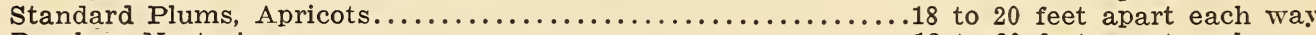
Peaches, Nectarines............................18 to 20 feet apart each way

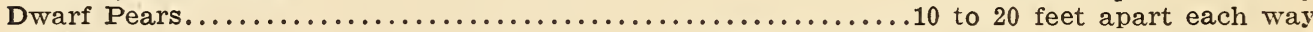

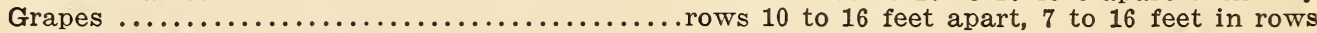
Currants and Gooseberries...................................... to 4 feet apart

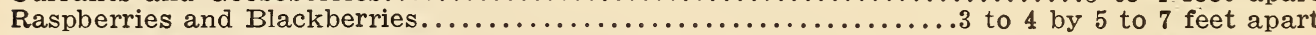
Strawberries for field culture.......................... to $1 \frac{1}{2}$ by 3 to 4 feet apart

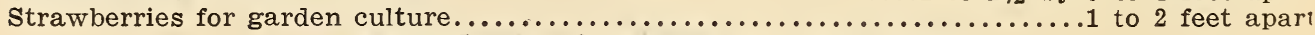

\section{Number of Trees on an Acre}

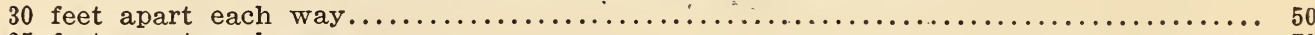

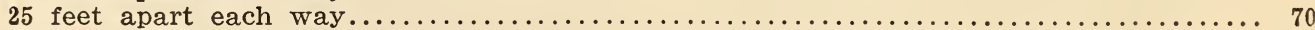

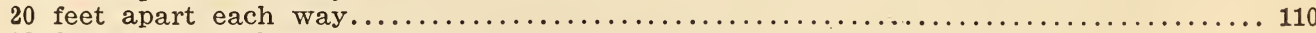

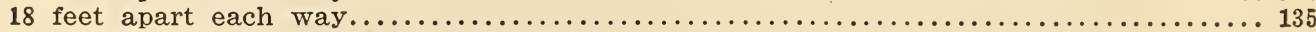

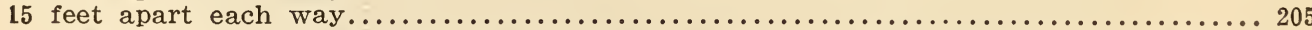

Rule-Multiply the distance in feet between the rows by the distance the plants are apart In the rows, and the product will be the number of square feet for each plant or hill; which. divided into the number of square feet in an acre $(43,560)$ will give the number of plants or trees to the acre. 


\section{A Few Words From Our Customers}

Saline Co., Mo.

The shipment of trees I ordered from you received today in fine shape. I am delighted with the trees and thank you so much for the extras. I will take pleasure in recommending your nursery to anyone who wants good trees and good treatment.

L. W. SUGGETT.

Boone Co., Mo.

I received the fruit trees by express and mu'st say that they were in excellent condition. We thank you very much for prompt attention. The trees were the finest, in the finest condition, of any I ever ordered. I shall recommend your trees to my neighbors. J. R. ANTHONY.

Randolph Co., Mo.

I received the grape vines in fine shape. I received the goods yesterday afternoon, and placed them in the ground this A. M., in good shape. This was record time for filling an order quickly, and the finest nursery stock I have ever seen. Any man who buys such fine stock as you have sent out to myself, who, if he plants his trees and vines in good condition, will be absolutely sure of results. It's the best stock I have ever seen, not even excepting my first order to you. You will get all my orders for nursery stock hereafter. I thank you for the extra vines, and the very prompt manner in which you filled the order.

ARTHUR ANDERSON.

Pettis Co., Mo.

Received my trees today and they are nice ones. Best one-year trees I ever saw.

CHAS. DUMP.

St. Louis Co., Mo.

I received my trees yesterday. They are a fine lot.

\section{AUGUST HILL.}

Bates Co., Mo.

I received the nursery stock today, all $\mathrm{O}$. $\mathrm{K}$. [t was in first-class shape and I am well pleased with it. I never saw nicer roots. [ called up some of my neighbors and told them what nice stock I got.

$$
\text { O. C. JOHNSON. }
$$

Barton Co., Mo.

Received order O. K. People well pleased, for which I was glad as they are some of my old customers. I can always recommend your stock.

$$
\text { B. KING. }
$$

$$
\text { Caldwell Co., Mo. }
$$

I received the trees all right. Am wel pleased with them, and also your prompt shipment. I also received your letter today with the money order enclosed. You people are honest, I know. I would much rather deal direct with the company than to deal with agents. I will do you all the good I can. GEORGE MOORE.

$$
\text { Jackson Co., Ill. }
$$

I am enclosing check and freight bill to cover for the 1100 peach trees. Trees have all arrived in good condition and am well pleased.

LEWIS R. ALLEN.

Calhoun Co., Ill.

Enclosed find check to balance as per statement. Trees came in good shape.

\section{CHRIS. RINGHAUSEN.}

Knox Co., Mo.

Stock arrived in splendid condition and gave good satisfaction

\section{CHARLES NORMILE.}

Henderson Co., Ill.

We have unpacked our nursery stock and It is satisfactory.
Tazewell Co., Ill. and I think they are as fine trees for the money as I could have gotten anywhere.

SILAS HUETTE.

Muskogee Co., Oklahoma.

The trees came through in fine shape. I thank you very much for the courtesy shown me this season.

JOHN F. SNEED.

Oklahoma Co., Okla.

I received the shipment in good order, and have a good season in which to set them out. (JUDGF) JOHN B. TURNER.

Uvalde Co., Texas.

Trees were fine size and the best roots I ever saw. T. B. OVERSTREET.

Trees received in fine shape. Am highly pleased with them.

JOHN P. BENDER.

Bristol Co., Mass.

Trees at hand today in good order. All nice ones.

GEORGE HARMON.

Pulaski Co., Indiana.

I have just received word from Mr. Holmes that he had received the shipment of trees from you folks all O. K., and said they looked good to him.

W. B. HENRY.

San Joaquin Co., Calif.

Enclosed find check to pay my account. The peach trees were a good lot of trees and I have had no trouble in disposing of them. The shade trees are all right, and I am selling them right along and they are giving good satisfaction.

\section{T. J. STEPHENS.}

Mesa Co., Colo.

My pear trees arrived in good shape. J. O. SIMMONS. Davis Co., Iowa.

I am well pleased with the bill of trees I received from you in April. Thanks for the gratis peach trees.

EPH SLOAN. Utah Co., Utah.

We prefer your peach trees to any we have ever handled.

\section{Nurseries.}

East Baton Rouge Co., La.

The shipment you forwarded me by mail on the 26 th ult., was received in excellent order. I. T. YOUNG. Jackson Co., Mo.

We received the bale of trees in good condition and think they are fine.

\section{W. H. WILLIAMSON \& CO.}

Moniteau Co., Mo.

Enclosed find check to balance my account with you. The trees you sent me were about the best I ever got. Thanks.

$$
\text { C. K. WILSON. }
$$

Marion Co., Ill.

I will have twenty-five cars of peaches this year. I sure have a fine orchard of the trees you sold me three years ago.

\section{WALTER WHITE.}

$$
\text { Christian Co., Mo. }
$$

We are well pleased with the shipment of trees, and same came through in good shape. - Nursery Co.

Marion Co., Ill.

The trees have been received and planted. We thank you for prompt filling of the order. PERRINE BROTHERS. 


\section{Certificate of Nursery Inspection}

\section{University of Missouri Agricultural Experiment Station, Columbia, Mo., August 29, 1921.}

This is to certify that, in accordance with the Nursery Inspection Act, passed by the Forty-seventh General Assembly, the nursery stock of the New Haven Nurseries, Nursery, grown at New Haven, Franklin County, Mo., was inspected on August 18, 1921, by a duly authorized inspector, and found apparently free from dangerously injurious insects or plant diseases.

LEONARD HASEMAN,

Entomologist and Chief Inspector.

E. S. LLOYD,

Deputy Inspector.

\section{Spraying}

Spraying is a vital necessity if money is to be made from fruit. It doesn't pay to miss one season, even if enemies are not visible. Spraying has an in. vigorating effect on trees, besides controlling enemies.

There are three classes of enemies spraying will control-chewing insects, sucking insects, and fungi. Each class requires a different remedy, but the remedies can be combined most of the time.

Spraying during the dormant period is distinctly different from spraying on foliage. Materials several times as strong can be used and are needed to control the scales.

On account of the life-habits of enemies, often only two to seven days are available for any one spraying. Do the work then. Put the material on with force and cover every inch of bark and leaf.

Get a sprayer that is big enough, that will give one hundred to two hundred and fifty pounds of air pressure, that is adapted to your land and trees, and that is durable. Get a power outfit, if possible, for it does better work than a hand-pump can.

The spraying programme ordinarily resolves itself into two, three or four applications-one while trees are dormant, with lime-sulphur solution, and the others on blossoms and fruit with self-boiled lime-sulphur, or diluted lime-sulphur, with arsenate of lead added, or maybe with Bordeaux and lead. All applications must be guided by careful study.

Borers will attack fruit trees in spite of all we can do, and will kill many trees if left alone. Trees must be gone over several times each year, and should be gone over each April and August.

\section{We Grow Our Own Stock}

We mail this list of prices to our friends and customers, and will ask that they favor us with their orders as early as practicable. We have now growing in our nurseries over one million fruit trees by actual count. All clean and healthy. ENTOMOLOGIST'S CERTIFICATE WITH EACH SHIPMENT. No San Jose Scale, Yellows or Rosette has been found in this County.

Shipments to Pacific Coast and Southern States from our frost-proof storage during winter months via Southern Routes.

WE ARE GROWERS OF WHAT WE SELL, having over 500 acres devoted exclusively to the nursery business. Many nurserymen are simply jobbers in the trade, and cannot sell stock with the same certainty of being true to name and free from disease.

\section{New Haven Nurseries}

\section{New Haven, Missouri}




\section{Order sheet NEW HAVEN NURSERIES}

\section{NEW HAVEN, Franklin County, Missouri.}

Name.

Post Office

County.

State

Date Shipment is Desired

Name of Railway Sration

Name of Railroad
Varieties of Trees, Eto., Wanted

..Date.

AMOUNT ENCLOSED:

Money Order -

Draft - - - \$.......

Cash - - -

Total.$--\ldots \ldots \ldots$

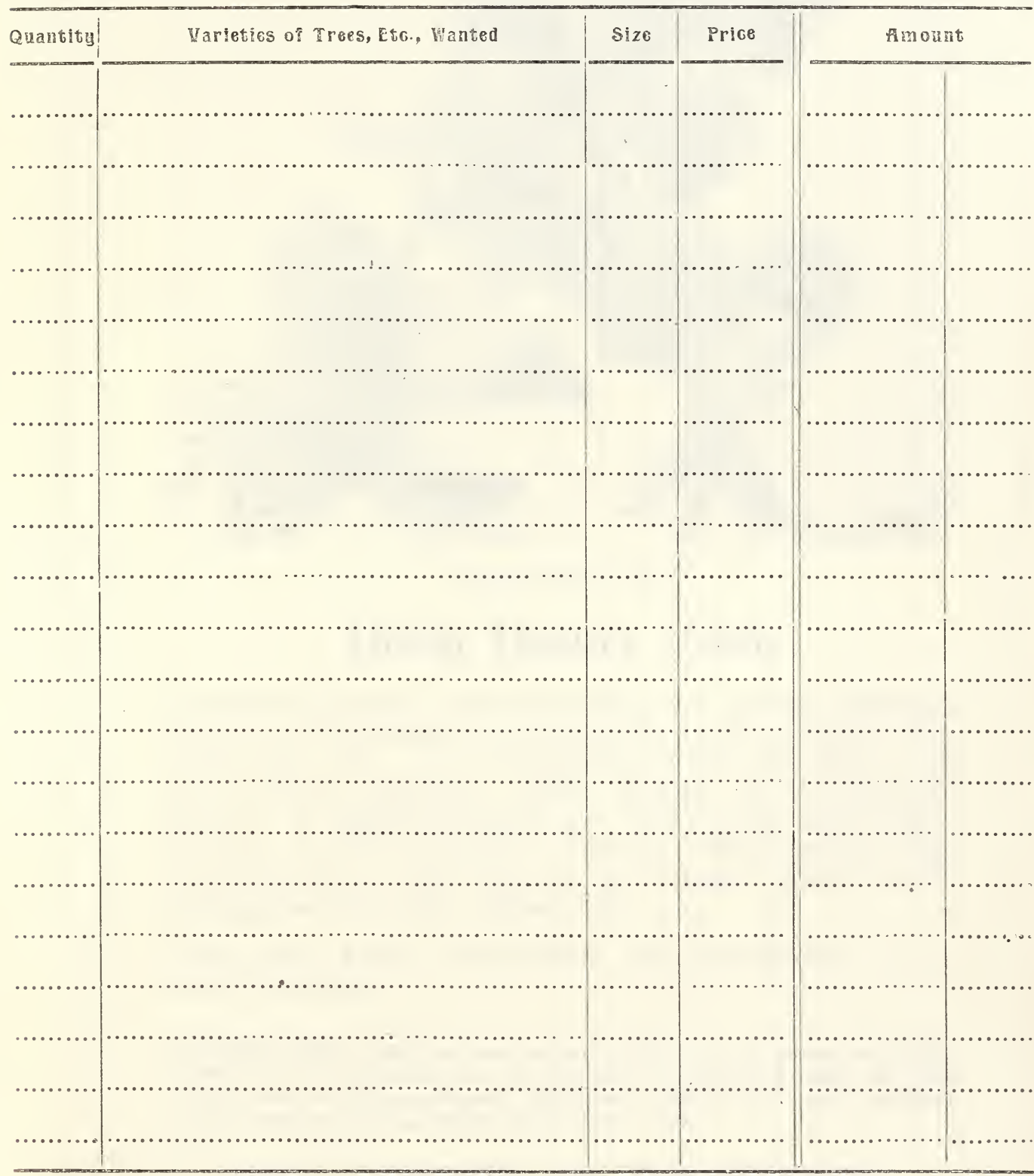




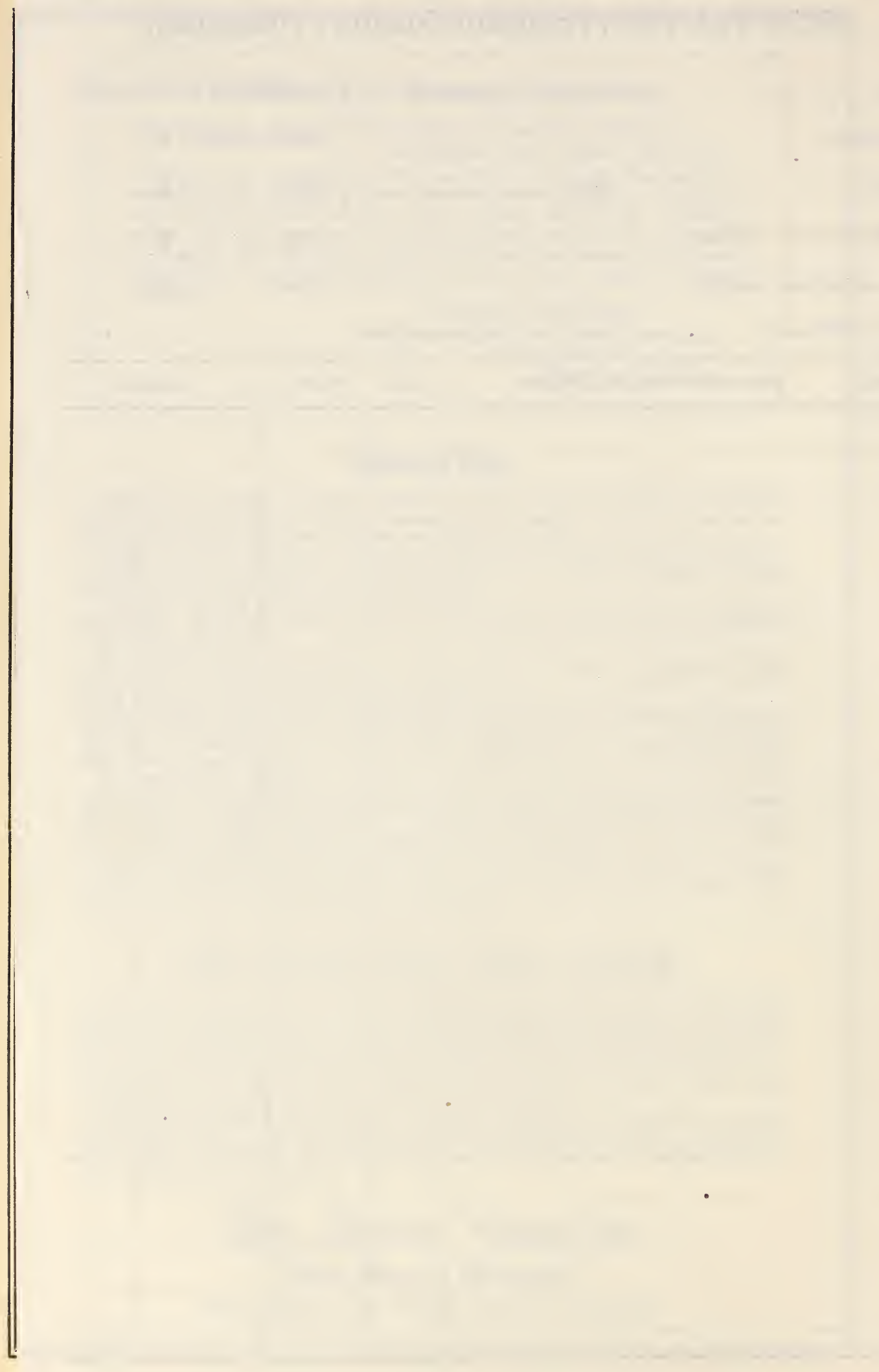




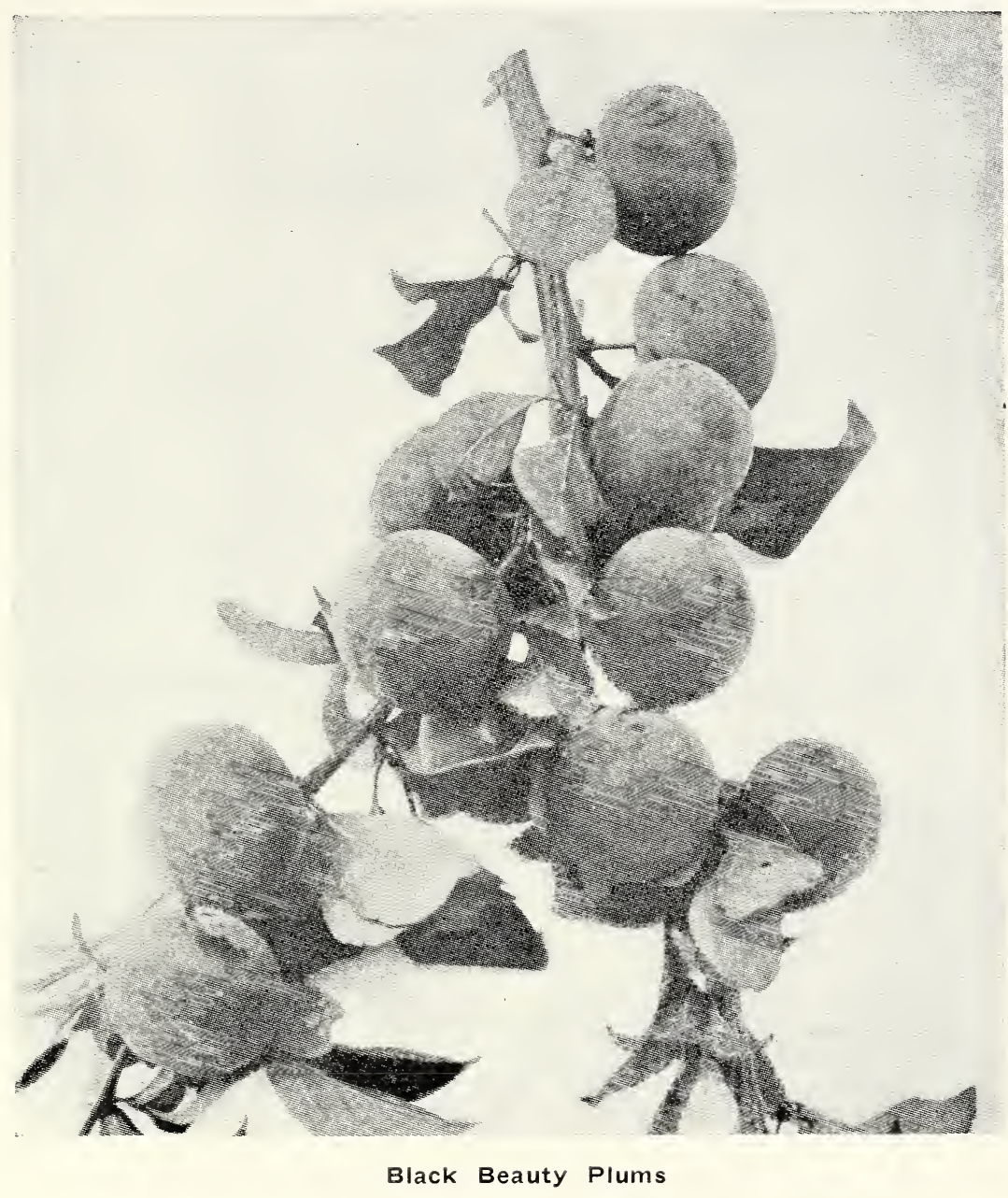

\section{Black Beauty Plum}

The Black Beauty is the Best Plum for general planting. Ripens with Burbank, is very dark purple, almost black when fully ripe. Is a cross between the Abundance and the Common Damson. When cooked has the Damson flavor. A splendid market sort, being more than double the size of the Shropshire Damson. This variety originated with us here, and we can supply genuine stock propagated from the original tree.

Price, each, $\$ 1.00 ; 10$ for $\$ 9.00 ; 100$ for $\$ 75.00 ; 4$ to 6 feet; first-class.

REFERENCES-Some of our correspondents have asked us to give them bank references, and we hereby comply, and refer to local banks and to the commercial agencies. We do our local business with Farmers Savings Bank, New Haven, Mo. 


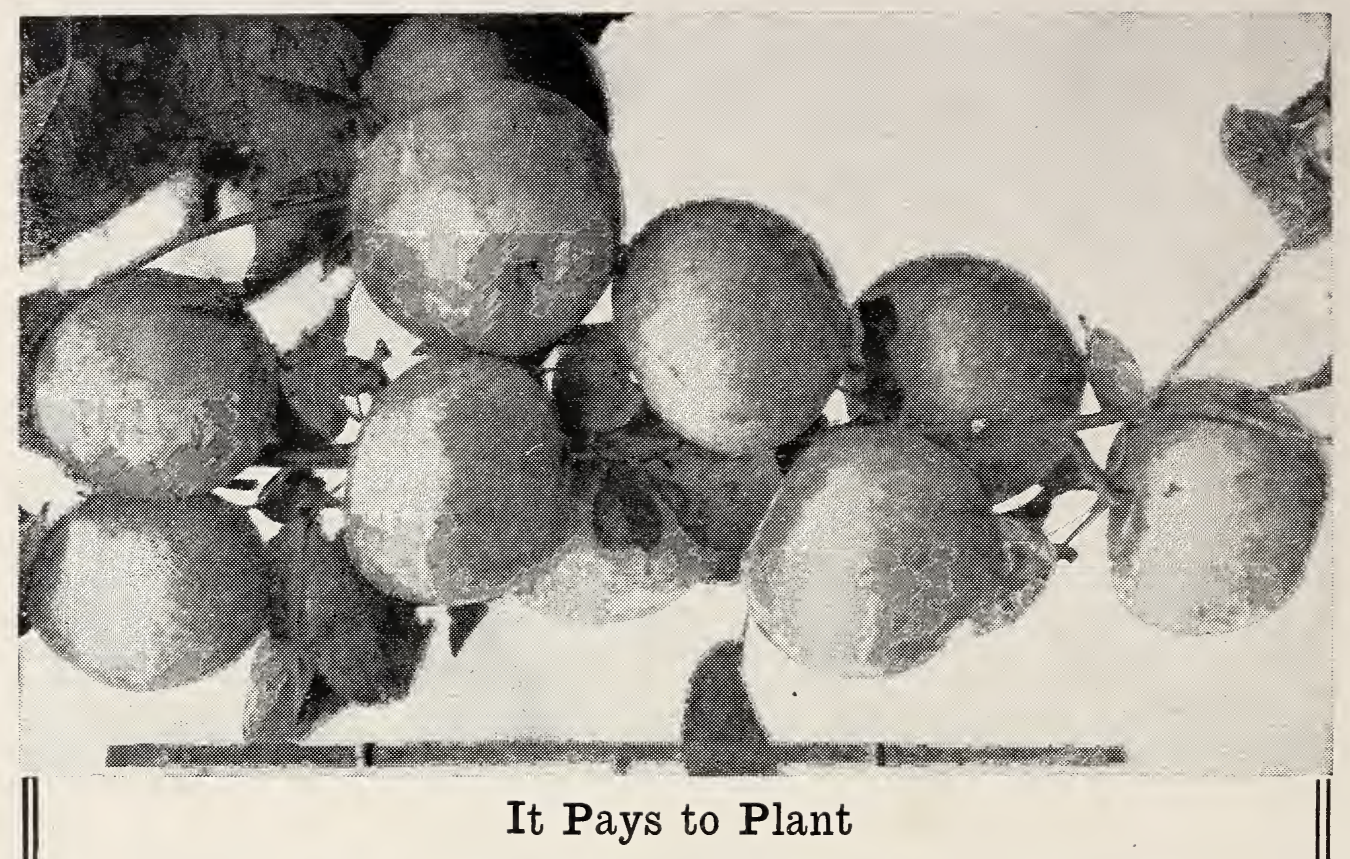

\section{BAGBY GROWN FRUIT TREES}

\section{They Grow and Bear True To Name}

W THEN you buy Fruit Trees, you want the best that can be produced. Bagby grown trees have been on the market for over fifty years. When you buy them you are getting the best money can purchase, and you know what the crop will be. Our varieties are correct, our grades full and all culls go on the brush pile. High quality and ABSOLUTE SAT. ISFACTION GUARANTEED, with a record of over fifty years square dealing to back the guarantee.

NEW HAVEN NURSERIES, New Haven, Missouri J. BAGBY \& SONS COMPANY

Bagby Trees are full of Vitality because Grown Right. They Bring Results.

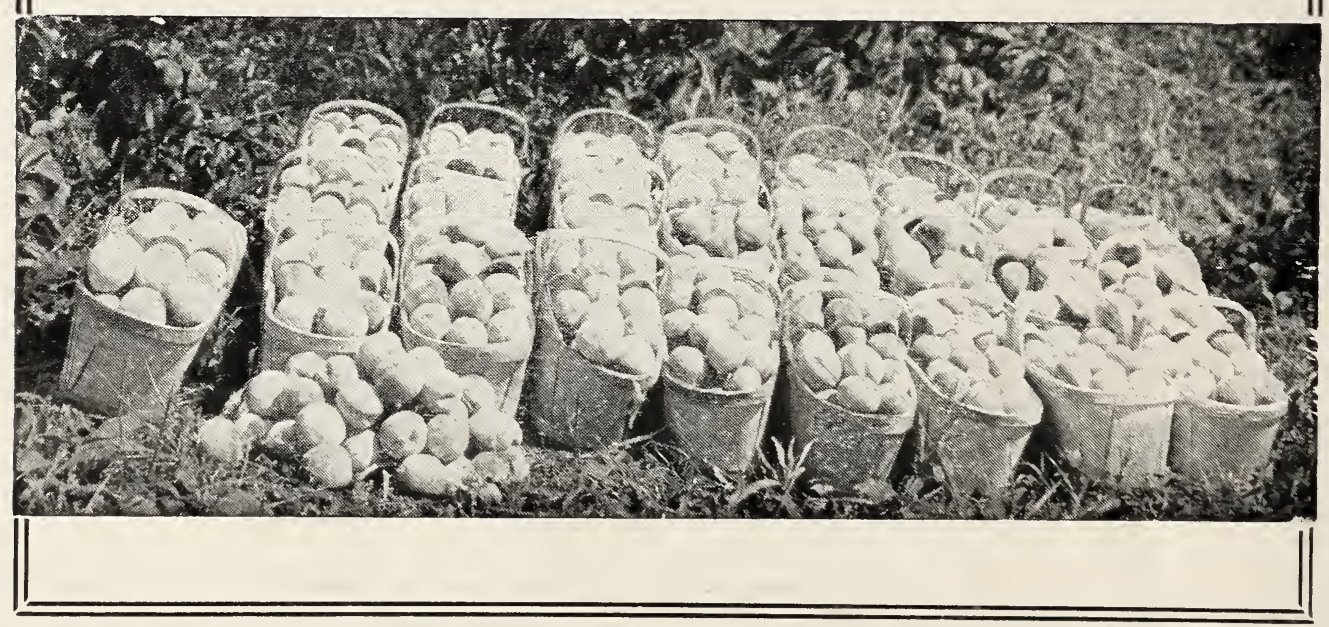

